\title{
Energy Sources of Microseisms in Sweden
}

\author{
Tetsuo A. Santo \\ Ricevuto il 6 Novembre 1962
}

\section{INTRODUCTION.}

Microseisms in Sandinavia have been so fully investigated and discussed from various points of view by Båth in a number of papers (1949, 1951a. 1951b, 1951c, 1953 and 1962) that we can hardly add anything by the same method. There is another statistical investigation by Zátopek (1961) about the relation between the positions of energy sources over the northermmost Atlantic Ocean and the microseism activity of Europe, including Scandinavia.

The present author made other kinds of investigations of the relation between microseisnic storms and the passage of cyclones, typhoons or cold fronts across or around Japan during I.G.Y., using data obtained at eleven stations along the Japanese Islands (Santo 1959a, 1959b and 1960). The writer found that microseisms with periods of 4 to 10 seconds are produced by standing ocean waves, due to interference between incident and reflected swells at some steep coasts.

Ile had favourable opportunity to investigate the microseisms at Firuna und Uppsala, Sweden, by means of the same method. The main purpose of the present work is to investigate the validity of the conclusion found for Japan.

The materials used were the $Z$ component amplitudes and periods of microseisms recorded at Kiruma by Galitzin seismographs and at Uppsala by Benioff long-period seismographs during I.G.Y. The weather maps published by the Swedish Meteorological and Hydrological Institute of Stockholm were used in order to find the energy sources of microseismic: storms. As the weather maps used show the situation only once a day, the energy soulces related to microseismic storms of shorter duration may sometimes be missing in the present investigation. 
Comparative studies were made of the positions of energy sources and every remarkable microseismic storm both of amplitude and period in every month from July, 1957, to December, 1958. As there were no microseismic storms in July, 1957, and in August, 1958, the description of microseisms in these two months will be omitted. The microseisms studied belong to the period range of 3-10 seconds.

COMPARATIVE STUDIES OF MTCROSEISMIC STORMS AND ENERGY SOURCES.

August, $195 \%$.

Time variations of amplitudes and periods of microseisms at $\mathrm{Ki}$ runa (K) and Uppsala (U) in August 1957 are shown in Fig. 1 by solid and dotted curves respectively. The time scale in this figure has vertical marks corresponding to $00 \mathrm{~h} 00 \mathrm{~m}$ on every day in G.M.T., and amplitude (ground displacement in microns) and period (seconds) scales are given on left side for Kiruna and on right side for Uppsala respectively. In average, the microseismic activity in this month was quite poor and the periods were rather short, around four seconds both at Kiruna and Uppsala. The measurements of periods are often interrupted because of zero amplitudes, especially at Uppsala. Amplitude curves show two isolated storms, a small but sharp one around $12 \mathrm{~d}$ 12h at Uppsala and a large one around $22 \mathrm{~d} 12 \mathrm{~h}$ at Kiruna. Figs 1-a to 1-c show the meteorological situations, which seem to be correlated with these microseismic storms. In these weather maps, positions and intensities of cyclonic centers at $06 \mathrm{~h}$ every clay are represented by different marks, as explained in the figure.

The microseismic storm in Fig. 1 at $12 \mathrm{~d} 12 \mathrm{~h}$ at Uppsala is quite remarkable, because microseismic storms are nearly always bigger at Kiruma than at Uppsala, as we shall see in the present paper. In the weather maps (Fig. 1-a), a cyclone at the eastern coast of Fngland at 11d $06 \mathrm{~h}$ moves northward, and separates into two at $12 \mathrm{~d} 06 \mathrm{~h}$, of which one is located at the middle part and the other at the southern edge of the Norwegian coast. As seen in the next case (Fig. 1-b), the passage of a cyclone across the central Norwegian coast does not have great effect upon the Uppsala microseisms. Further, as we shall also recognize by many cases later, the passage of such an unimportant cyclone $(995 \mathrm{mb})$ through the southern edge of the Norwegian coast cannot give a remarkable effect upon the Uppsala microseisms. Therefore, we can hardly say that the microseismic storm at Uppsala may be caused 
by any of these cyclones at 12d 06h. MLorevere, as this storm started at Uppsala already from the brginning of the 11 th, we cannot suggest:
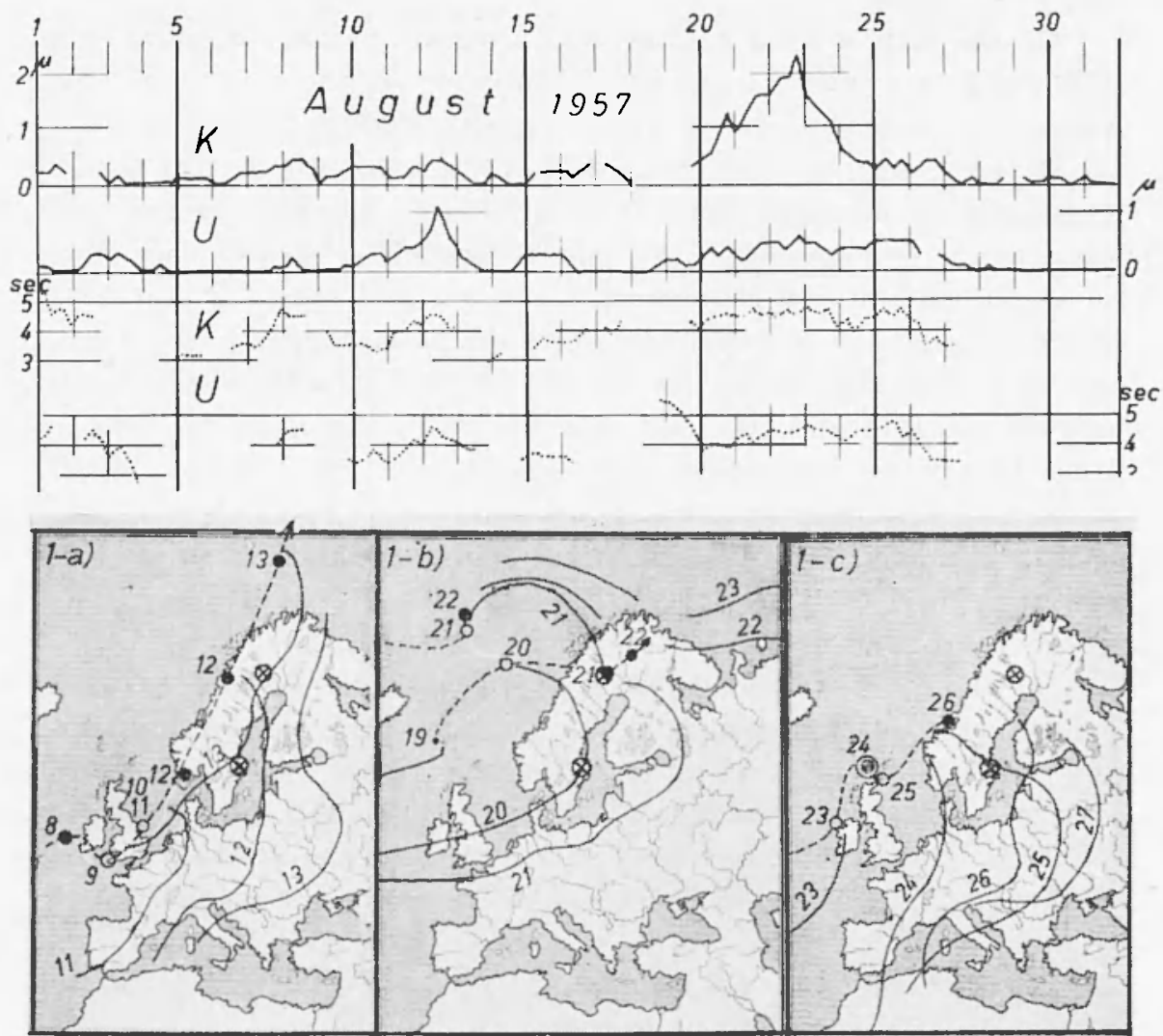

- $p \geq 1000 \mathrm{mb}$

$990 \mathrm{mb} \leq n \leq 999 \mathrm{mb}$. ० $980 \mathrm{mb} \leq p_{0} \leq 989 \mathrm{mt}$, ० $970 \mathrm{mh} \leq \mathrm{a} \leq 979 \mathrm{mt}$,

(-) $960 \mathrm{mb} \leq p_{0} \leqq 969 \mathrm{mb}$, (O) $950 \mathrm{mb} \leq p_{0} \leq 959 \mathrm{mb}$, (O) $p_{\mathrm{o}} \leq 949 \mathrm{mb}$

cold front, -..- cyclonic poth.

Fig. 1 - Amplitudes (solid curves) and periods (dotted curves) of microseisms at Kiruna (K) and Uppsala (U) in August, 1957, a-c: Weather maps with positions of eyclones and cold fronts every day at 06 h GWT. The numerals indicate the dates. Kiruna (northern station) and Uppsala (sonthern one) are marked in all maps.

that it occurred due to some other cause which appeared and disappeared suddenly near Uppsala and was missed on the wather maps of once a day. Furthermore, as will be shown later, the passage of a cold front across the Baltic Sea has a slight effect upon short-period microseisms 
but not upon those of more than 4 seconds at Uppsala. Considering this, we suggest that this peraliar storm is caused by the additive effect of the two cyciones.

On the 19 th, a weak cyclone with a central pressure of more than $1000 \mathrm{mb}$ passed over Kiruna and disappeared on the 23rd (Fig. 1-b). A large microseismic storm at Kirma from the 20th to $23 \mathrm{rd}$ is no doubt due to the passage of this cyclone. It is strange, however, that such a remarkable microseismic storm is so isolated to Kiruma. Perhaps the origin of the microseisms in this case is located on such a place from where the transmission of microseismic waves to Ippsala is prevented due to some geological complexity along the path. In spite of the passage of a cold front across the middle and southern Norwegian coast between the 19 th and 20 th and over the Baltic Sea from the 20 th to 21st, there is no remarkable microseismic: storm at Uppsala. Short period Benioff seismograms at Uppsala, on the other hand, show a slight activity of microseisms of less than 1 second period, related to the passage of the cold front over the Baltic: Sea. We shall have many other similar cases later.

On the $23 \mathrm{r}$, another cyclone approached the western coast of Ireland, with a path as shown in Fig. 1-c: with a minimum central pressure of $965 \mathrm{mb}$ on the $2.4 \mathrm{th}$. The pressure increased gradually and the cyclone had almost disappeared on the 27 th at the same position as on the 26th. Both the approach of a moderate ayclone to the southern coast of Norway and the sweeping of a cold front from the 24th to 26th over the same coast keep the microseismic amplitudes at Uppsala a little higher than at Kiruna.

In Fig. 1-c, a large microseismic storm may be expected around the 24th from the passage of an intensive cyclone near the British coast. Nevertheless, there is no increase of microseismic amplitudes, not even at Uppsala. This indicates that microseismic: waves do not propagate through the ocean between England and Scandinavia.

\section{September, $19.5 \%$.}

There are two microseismic storms (Fig. 2). The first one with a duration from the 6th to the 17th has two peaks around 10d o0h and 14t 12h at Kiruna. In the corresponding interval, a strong cyclone appeared west of England, which changed its direction to northward on the 6th, as shown in Fig. 2-a. Its central pressure became minimum on the 7 th $(965 \mathrm{mb})$ and then increased gladually. The first peak at 
Kiruna around $09 \mathrm{~d} 12 \mathrm{~h}$ can be connected with the approach of this cyclone to the north-western coast of Norway. Periods of microseisms at Kiruna also show a little increase by the passage of this cyclone
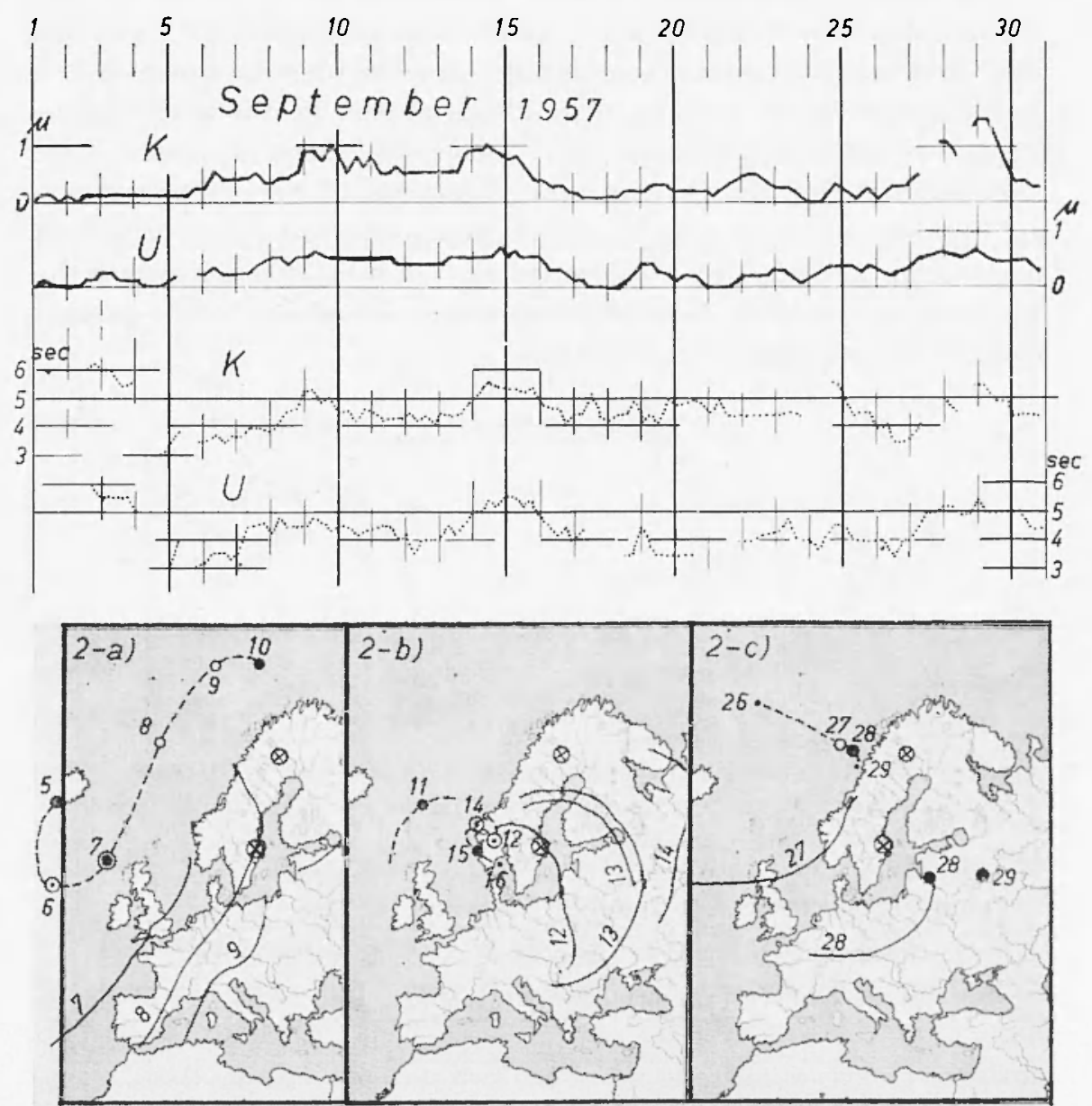

Fig. 2 - Amplitudes and periods of microseisms and weather situations in september, 1957 .

along a path, at a distance from the coast. It must be noticed that in spite of the travel of such an effective disturbance $(980 \mathrm{mb}$ both on the 8th and the 9th) from south to north parallel to the Norwegian coast, the microseismic stom appeared at Kiruma only when the source came to the north. This fact suggests that the origin of the microseismic 
storm on the 9th is located on the northern coast of Norway and that the propagation of microseismic waves from this origin to Kiruna is much easier than to Uppsala.

A small ayclone arrived at south Norway on the 12th with increasing intensity (970 mb; Fig. 2-b). It went around in a small region till the 15th, loosing its energy gradually. A cold front passed over the Baltic Sea from the 12th to the 13th, as shown in the same figure. These two situations, however, gave almost no change of microseismic amplitudes at Lippsala. Seismograms of short-period Benioff instruments at Uppsala during the same period were examined. Amplitudes of microseisms around one second period showed a little increase from the begiming of the 12th. This little storm may be caused by the passage of the cold front across the Baltic Sea.

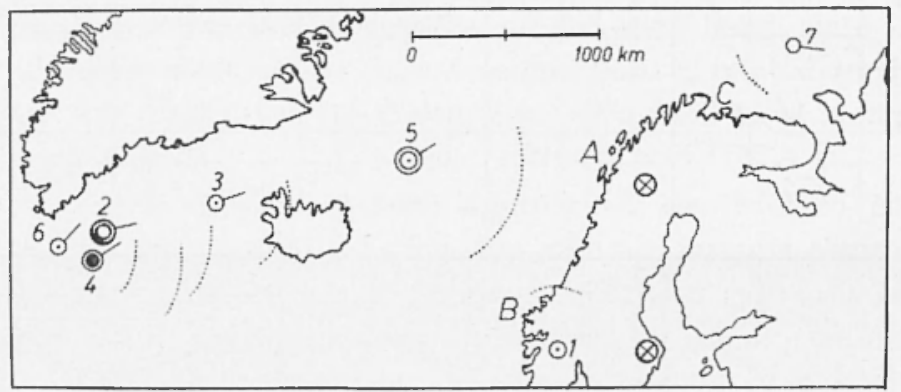

I'ig. 3 - Positions of distant cyelones from October to November, 1957. Short bars at every cyclonic center mean the direction of cyclonic movement. Parts of the limits of the "oye of microseismic storm" are shown by dotted curves around each cyclonic center. Cyclone numbers correspond to those in Table I.

A microseismic storm occurred at Kirma with a remarkable time delay after the arrival of the cyclone mentioned. There is a parallel increase of periods of mieroseisms at the two stations. From these observational facts, we suggest that the microseismic storm is produced by the long-period swell at some coast, distant from the energy source. This suggestion was checked by the following method.

The cyclone became intensive on the 12th. We introduce the conception of the " "ye of microseismic storm" (sec Appendix) around a cyclonic center, considering the situation on the 12th (see the cyclone No. 1 in Fig. 3). Taking into account the central pressure of $970 \mathrm{mb}$ as well as its stationary state at that time, about $300 \mathrm{~km}$ may be taken as the radius of the "eye". The travelling distance for the swell from 
the edge of this " eye" to the coast nearest to Kiruna is approximately $750 \mathrm{~km}$. The group velocity of swell with a period $T_{w}$ of 11 seconds (twice the observed period of microseisms at $14 \mathrm{~d} 12 \mathrm{~h}$ ) was calculated as $24 \mathrm{~km} / \mathrm{hr}$ from the formula $v=g T_{w} / 4 \pi(\mathrm{cm} / \mathrm{sec})$, given by Unoki (1956), in which $g$ is the gravitational constant. The travel time of swell becomes about 31 hours, i.e. the swell must have reached that coast at 14d 16h (Table I). This result nearly corresponds to the peak of the storm in question.

Table I - Estimated arrival times of swells - (September to November, 1957).

\begin{tabular}{|c|c|c|c|c|c|c|c|c|c|c|}
\hline N. & & $\begin{array}{l}\text { ate } \\
\text { MI } \\
\text { d }\end{array}$ & h & $\begin{array}{l}p_{0} \\
m b\end{array}$ & $\begin{array}{c}D-D c \\
\mathrm{~km}\end{array}$ & $\begin{array}{c}v \\
\lim / \mathrm{hr}\end{array}$ & $\begin{array}{c}t \\
\mathrm{hr}\end{array}$ & \multicolumn{2}{|c|}{$T$} & $\mathrm{C}$ \\
\hline 1 & Sept. & 13 & 06 & 970 & 750 & 22 & 34 & 14 & 16 & A \\
\hline 2 & Oet. & 07 & 06 & 955 & 1700 & 28 & 61 & 09 & 19 & A \\
\hline & & & & & 1400 & 26 & 54 & 09 & 12 & B \\
\hline 3 & $n$ & 08 & 06 & 975 & 1400 & 30 & 47 & 10 & 05 & $A$ \\
\hline & & & & & 1100 & 28 & 39 & 09 & 21 & B \\
\hline 4 & ) & 14 & 06 & 960 & 1500 & 26 & 58 & 16 & 16 & B \\
\hline 5 & D & 27 & 06 & 945 & 450 & 26 & 17 & 27 & 23 & B \\
\hline 6 & $n$ & 30 & 06 & 970 & 1900 & 35 & 54 & 01 & 12 & B \\
\hline 7 & Nov. & 15 & 06 & 980 & 250 & 22 & 11 & 15 & 17 & $\mathrm{C}$ \\
\hline
\end{tabular}

It may be questioned how stationary swell could occur by the swell travelling almost parallel to the coast. But, as is well-known, the wave fronts tend to become parallel to the coast when entering into shallower water. Moreover, even if the coast seems to be parallel to the paths of swell in general, there are many parts of the coast, which face the coning swell almost perpendicularly. In front of such steep coasts, stationary swell can easily arise due to interference between the incident and reflected swells. 
In the following, we shall see many cases when periods of microseisms show a remarkable increase with a great time lag in relation to the appearance of a single distant cyclone over the ocean. In such cases, the same estimate concerning the arrival times of swell from a distant energy source to a certain part of the Norwegian coast will be made, and we shall see in every case a good time agreement between the calculated arrival of swell and the observed microseismic storm.

The last peak of mieroseismic amplitudes at Kiruna can be related to the approach of a cyclone to the central part of the Norwegian coast (Fig. 2-(c).

October, $19.5 \%$.

In this month, the disturbance sourees ran over the ocean around Scandinavia successively, which mate the mieroseisms quite active. The average amplitudes as well as periods became large compared to the preceding months. The ampliturle scale in this month (Fig. 4) was reduced to half of the preceding months in order to show the peak of the microseismic storm at $28 \mathrm{~d} 12 \mathrm{~h}$ within a certain limit.

From the 3rd to the 4th, a cyclonic center passed over Uppsala and another approached the northern coast of Norway (Fig. 4-a). The storm at Kiruna around $04 d$ ool can be connected with the latter source. The one at Uppsala in the same interval might be caused by the arditive effect of the other southern eyclone. As the southern cyclone was rather intense $(980 \mathrm{mb}$ at $04 \mathrm{l} 06 \mathrm{~h})$, a coast effect at the Baltic Sea near Uppsala would be sufficiently large to increase the microseismic: ampliturles at Uppsala to the same level as at Kiruna. Short-period Beniofe seimmographs at Uppsala also recorded a microseismic storm around the the with the period of 1-3 sec.

There was a remarkable increase of periods at Kiruna as well as at Uppsala from the 9th. The energy source of this period storm was an intensive cyclone off eastern coast of southern Greenland on the 7 th (cyclone No. 2 in Fig. 3). It approached Iceland on the 8th (No. 3 in Fig. 3) and then ran over the ocean with a course as shown in Fig. 4-b. Estimates of the arrival times of swell were made for two situations: $07 d 06 \mathrm{~h}$ and $08 \mathrm{~d} 06 \mathrm{~h}$. Rardii of $600 \mathrm{~km}$ and $400 \mathrm{~km}$ were assumed for the "ye of microseismic storms" towards the Norwegian coast around the centers, taking into aceount both the moving directions and the central pressures of $955 \mathrm{mb}$ and $975 \mathrm{mb}$ at these times, respectively. As periods began to increase at Uppsala a little earlier than at Kiruna, 

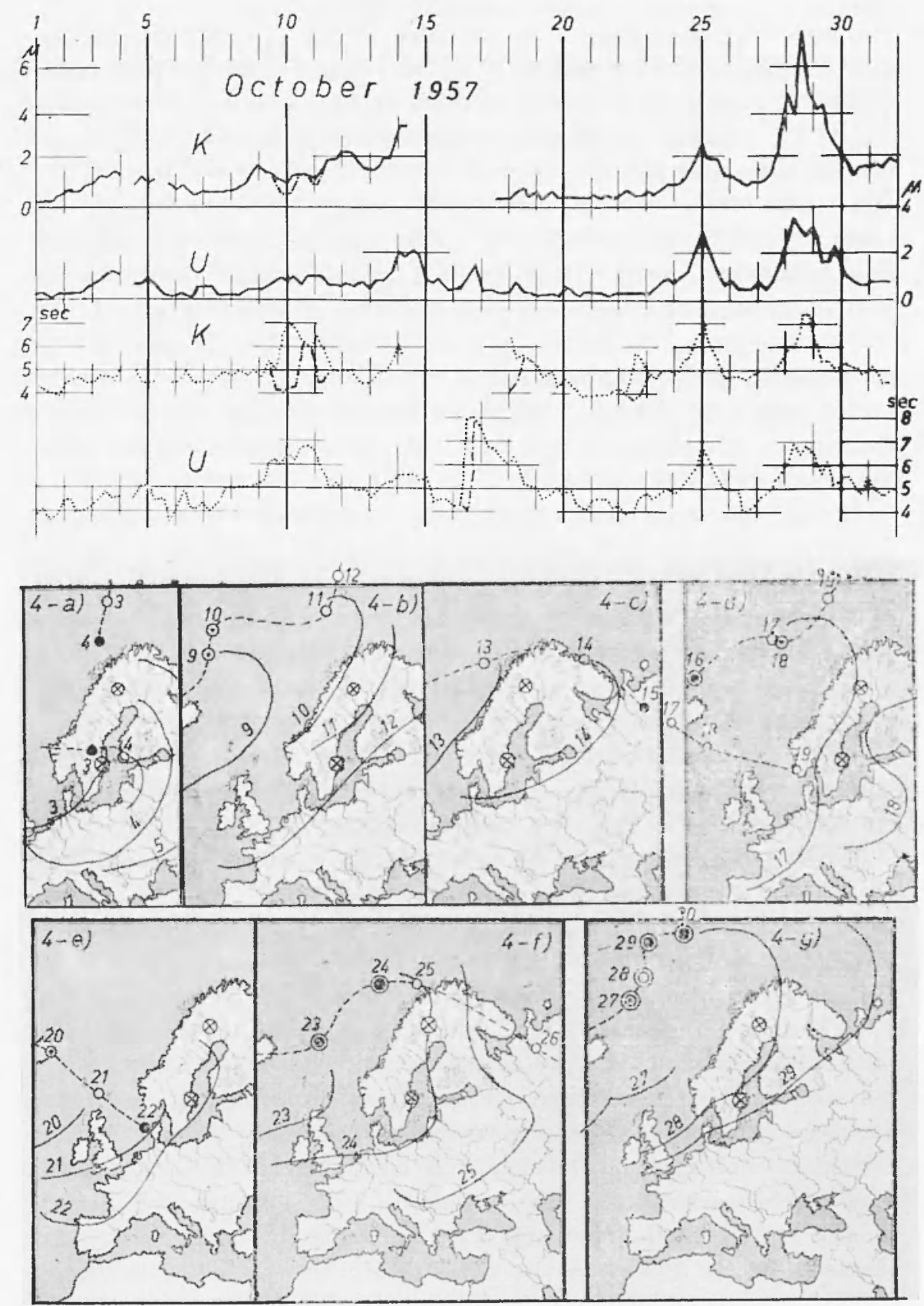

Fig. 4-Amplitudes and periods of microseisms and weather sitnations in October, 1957. When two kinds of microseisms are measured simultaneonsiy, the curves referring to shorter period microseisms are dashilotted. 
two arrival times of swell were estimated in this case, i.e. one for the northern roast (about $A$ in Fig. 3) and the other for the southern coast (about B). In these alculations (Table I), for the case of the cyclone No. 2, for instance, the periods of swell were taken as 14 seconds for the northern coast $\Lambda$ and 12 seconds for the southern coast $B$, respectively. The reason is that the observed periods of microseisms at the beginning of the storms at Kiruna and at Uppsala were $\tau$ seconds and f) seconds, respectively. The calculated arrival times of swell coincide well with the times of observer period increase at both stations.

Instearl, if we assume the periors of swell to be the same as for the observed microseisms, the velocity of swell from the cyclone No. 2, to the coast $A$ for instance, becomes $14 \mathrm{~km} / \mathrm{hr}$. Then, it is rasily found that the swell must reach $A$ at 12 d $08 \mathrm{~h}$. But, this result difiers markedly from the observations.

There is another fact to be noticerl. By the cyclones No. 2 and 3, a large microseismic storm must oceur on Greenland and Iceland respectively around the 7 th and the Sth. These storms, however, did not appear at all at the two stations in Swerlen. This means that microseismic waves do not propagate over the ocean to Scandinavia. The same results have been obtained by Båth (1953) and Monakhov (1959, 1960). We shall find the same result in many following cases.

Kiruna recorded another short-period nicroseismic storm at the same time. This can be explained by a cold front which swept the northern coast of Norway from the 10th to the 11th (Fig. 4-b).

A moderate cyclone and an accompanying cold front passed across the northern Scandinavia from the 13th to the 14th (Fig. 4-c). It is certain that the simultaneous ampliturle increase from the 13 th at both stations is comnerted with this meteorological situation. But, it is difficult to distinguish the microseismic effects of the cyclone and the cold front from the weather maps of once a day only. The ampliturle ratio between Kiruna and Uppsala was about $1: 0.5$ on the 13th. Nearly the same value will be found for many cases when the microseismic origin is located at some eoast in northern Scandinavia.

There was a strong cyclone $\left(p_{0}=960 \mathrm{mb}\right)$ off the sonth-eastern coast of (treenland at 1 th $06 \mathrm{~h}$ (eyclone No. 4 in Fig. 3). The arrival time of swell from the limit of "eye" around the cyclonic center' was estimated as $16 \mathrm{~d} 16 \mathrm{~h}$ (Table I), which nearly corresponds to the time of great increase of microseismic periorls at Uppsala. The path of this cyclone from the 16th to the 19th is shown in Fig. 4-rl. The extraorclinary rapid increase of the periorls at that time is considered to be due 
to the disappearance of another eyclone on the 16th (the position of this cyclone on the 15th is shown in Fig. 4-c), from which the swell disturbed the long-period swell from the distant source till that time.

It must be noticed that in spite of the appearance of another distant energy source at 17 d $06 \mathrm{~h}$ at the south-western coast of Iceland (Fig. 4-d), there is no increase of periods which could be expected about two days later, i.e. about the 19th. The reason is clear. There is another source from the 17th to the 19th much nearer to the coast, and therefore, the swell due to this cyclone disturbs the long-period swell from the distant cyclone. We shall find many such cases later. They demonstrate that period increase of microseisms occurs only when there is no other important disturbance of the swell from a distant source.

Tn the same map (Fig. 4-d), we see that the approach of a cyclone at the southermmost edge of Norway on the 19 th $\left(p_{0}=980 \mathrm{mb}\right)$ does not have any effect upon the microseismic amplitudes, not even at Uppsala. Quite the same result is found in Fig. 4-e. In this case, Uppsala is also quite calm. A remarkable peak of both amplitudes and periods on the 25th at both stations is certainly comnected with the weather situation shown in Fig. 4-f.

A cyclone arriving from west has become very intense with a central pressure of $945 \mathrm{mb}$ on the 27th (Fig. 4-g). In this case, a microseismic "eye" with a radius of $700 \mathrm{~km}$ was supposed around the center towards the Norwegian coast (cyclone No. 5 in Fig. 3). The arrival time of swell from this fringe to the southern coast was calculated as $27 \mathrm{~d} 23 \mathrm{~h}$ (Table I), which also corresponds well to the beginning of the period storms of microseisms actually observed.

November, $195 \%$.

A rapid increase of microseismic period on the 2 nd can be well explained by long-period swell from the limit of "eye" around the cyclonic center $(970 \mathrm{mb})$ which appeared on October 30 th at the southern edge of Greenland (cyclone No. 6 in Fig. 3). In this case, the arrival time of swell at the nearest Norwegian coast was estimated as 01d 12h (Table I), which also agrees well with the time of the beginning of the microseismic period storm. In this case, there are also other near cyclones at the same time (Fig. 5-a). A great difference between the swell periods due to these cyclones can be supposed (they might be around 17 seconds and 9 seconds respectively as judged by the observed microseismic periods). Therefore, microseismic periods and ampli- 
tudes produced by these different energy sources are measured separately as shown in Fig. ó.
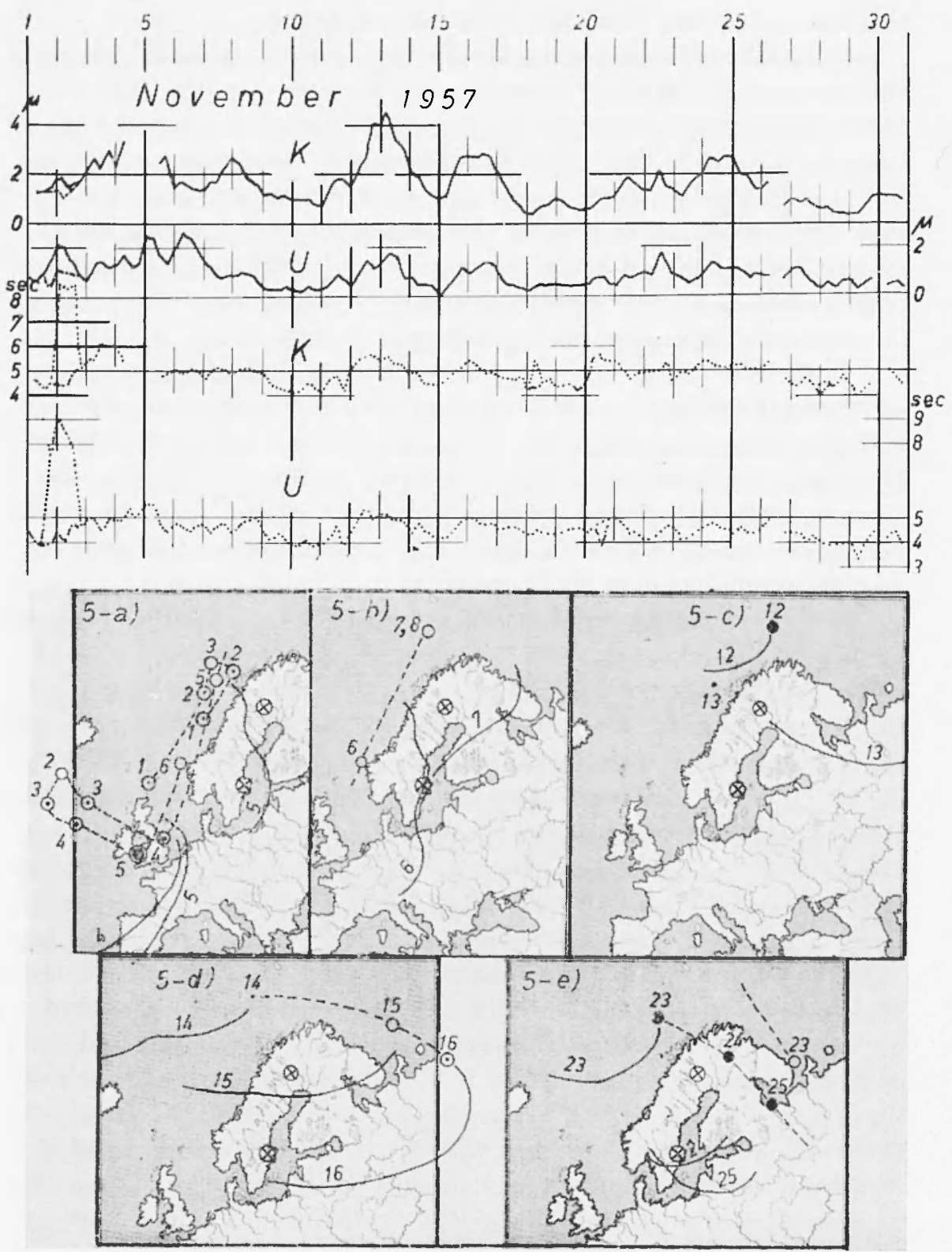

Fig. 5 - Amplitudes and perions of microseisms and weather situations in November, 1957. 
A microseismic storm with rather high amplitudes lasting from the beginning of this month to the 9 th at both stations, would be produced by two successive cyclones with similar paths (Fig. o-a and -b). The amplitude peaks around $05 d 00 \mathrm{~h}$ and $06 \mathrm{~d}$ 12h at Uppsala might be cansed by the successive moderate cyclones at the south Norwegrian coast not far from Uppsala. The second peak in the Kiruna amplitude curve around $08 \mathrm{~d}$ 00h is considered to be caused by the eyclone which stayed in the same position (Fig. 5-b). The third large peak around 13d 00h at Kiruna, probably caused by a cold front or a cyclone on the 12th (Fig. 5-c), is extremely high compared with the weakness of the cyclone. This fact also tells how Kirma microseisms are sensitive to energy sources off the northern coast of Scandinavia. The simultaneous microseismic storm at Uppsala must have the same northern origin as at Kirma. This is also suggested by the similarity of amplitude variation at the two stations. The amplitude ratio between Kirma and Uppsala is about $1: 0.4$.

The same can be salid for the following storm around 16a 06h (Fig. 5-d). A remarkable delay of maximum amplitudes in this case is due to later increase of energy. This suggestion is verified by the estimate of arrival time of swell from the cyclone of 15 d $06 \mathrm{~h}$ to the coast $\mathrm{C}$ (eyclone No. 7 in Fig. 3 and Table I). The estimated arrival time of swell (15d 17h) agrees very well with the observed beginning of the microseismic storm. Microseisnic waves at Uppsala would come from the same northern origin as for Kiruna. The amplitude ratio Kiruna: Uppsala is about $1: 0.5$.

From the 20th, small cyclones or weak cold fronts passed over Scandinavia successively till the 25th. Irregular noisy situation of microseismic amplitudes at the two stations seems to result from these sources. A remarkable increase of amplitudes from the $23 \mathrm{rd}$ at Kiruna is surely caused by a cyclone, passing across the Norwegian coast near the station (Fig. 5-e).

\section{December, $195 \%$.}

There were many microseismic storms in this month. The average microseismic amplitudes reached $2, \mu$ at Firuna and nearly $2, \mu$ at Uppsalat. The periods also often increased beyond 6 seconds. This is due to the fact that in this month, cyclones with rather high intensity successively passed across or around Scandinavia. At first, a small but developing cyclone passed over the northern coast of Scandinavia 

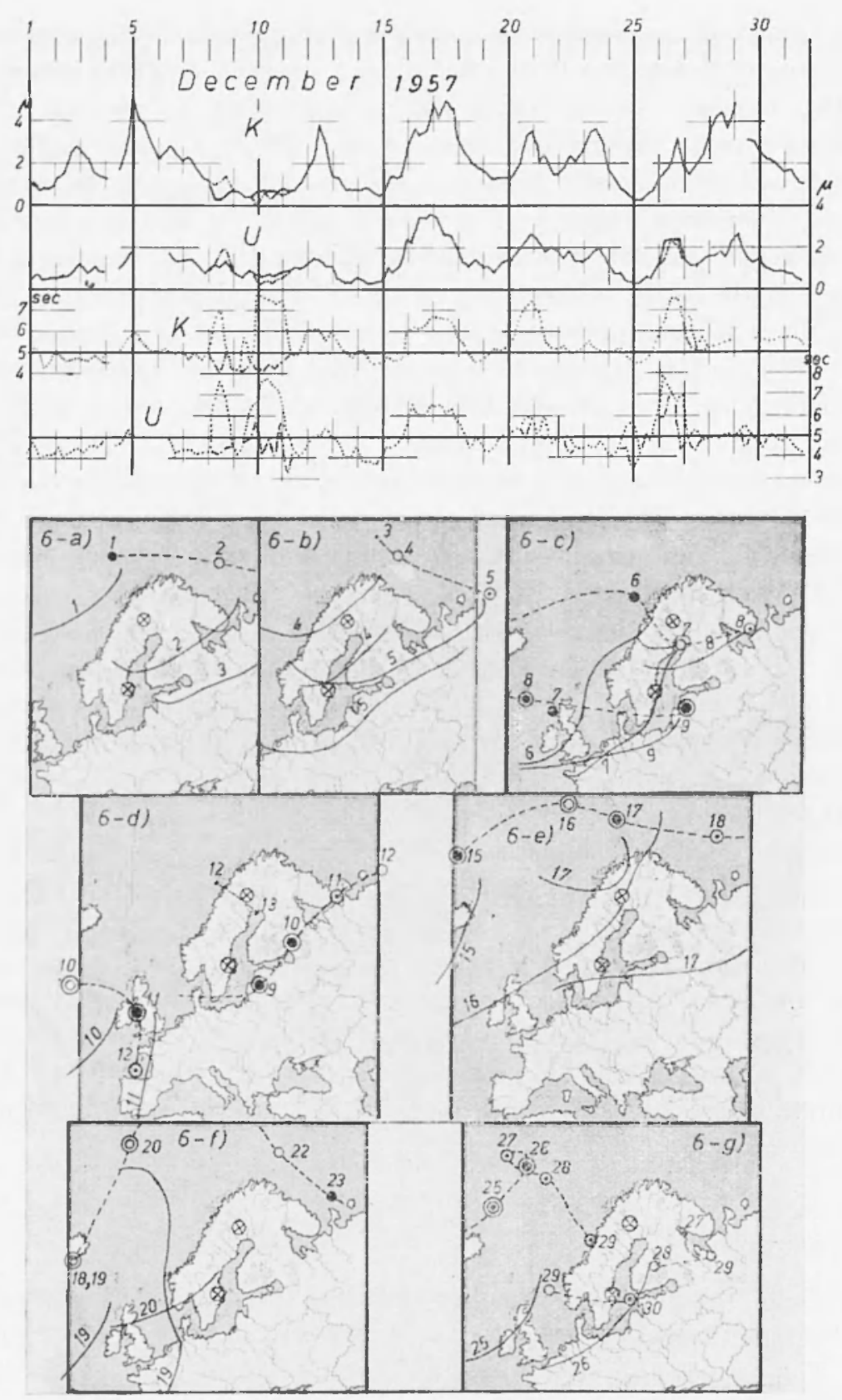

Fig. 6 - Amplitudes and periods of microseisms and weather situations in December, 1957. 
(Fig. 6-a). The next passage of a developing cyclone (Fig. 6-b) made a remarkable storm at Kiruna. As for the time lags of peaks against the passages of these two cyclones, the same conclusion can be made as for $16 \mathrm{~d}$ 12h, November 1957 (Fig. 5-d).

Table II - Estimated arrival times of swell.s - (December, 1957).

\begin{tabular}{|c|c|c|c|c|c|c|c|c|c|c|}
\hline N. & & $\begin{array}{c}\text { ate } \\
\text { M'T } \\
d\end{array}$ & li & $\begin{array}{l}p_{0} \\
\mathrm{mb}\end{array}$ & $\begin{array}{c}D-D_{0} \\
\mathrm{~km}\end{array}$ & $\begin{array}{c}v \\
\lim / \mathrm{hr}\end{array}$ & $\begin{array}{l}t \\
\mathrm{hr}\end{array}$ & $\mathrm{d}$ & h & C; \\
\hline \multirow[t]{2}{*}{8} & Dec. & 06 & 06 & 990 & 1700 & 30 & 57 & 08 & 15 & A \\
\hline & & & & & 1300 & 30 & 43 & 08 & 01 & 13 \\
\hline \multirow[t]{2}{*}{0} & $"$ & 08 & 06 & 965 & 1500 & 32 & 47 & 10 & 01 & $A$ \\
\hline & & & & & 700 & 32 & 22 & 09 & 04 & I3 \\
\hline 10 & $"$ & 11 & 06 & 970 & 350 & 26 & 13 & 11 & 19 & C \\
\hline 11 & $"$ & 12 & 06 & 980 & 700 & 26 & 27 & 13 & 09 & $\mathrm{C}$ \\
\hline \multirow[t]{2}{*}{12} & $"$ & 15 & 06 & 960 & 700 & 26 & 27 & 16 & 09 & $A$ \\
\hline & & & & & 700 & 26 & 27 & 16 & 09 & 13 \\
\hline 13 & $"$ & 16 & 06 & 950 & 250 & 26 & 10 & 16 & 16 & $A$ \\
\hline 14 & $n$ & 19 & 06 & 995 & 500 & 24 & 21 & 20 & 03 & B \\
\hline 15 & $"$ & 20 & 06 & 955 & 700 & 30 & 23 & 21 & 05 & $A$ \\
\hline \multirow[t]{2}{*}{16} & $"$ & 25 & 06 & 950 & 600 & 26 & 23 & 26 & 05 & $A$ \\
\hline & & & & & 400 & 26 & 15 & 25 & 21 & B \\
\hline 17 & $"$ & 26 & 06 & 960 & 700 & 30 & 23 & 27 & 05 & $A$ \\
\hline
\end{tabular}

Due to a following moderate cyclone, passing through the midrle part of Scandinavia (Fig. 6-c), the amplitudes of microseisms at both stations remained rather high till the 7 th.

A rapid increase of microseismic periods at both stations at 08d 12h can be explained by the appearance of a cyclone off western coast of Greenland (cyclone No. 8 in Fig. 7). The estimated arrival time of swell from the fringe of the "eye" at 06d 06h (Table II) agrees quite well with the time of observed microseismic period increase. Because of a near energy source at the easternmost coast of White Sar around the same time (Fig. 6-c), short-period minroseisms due to the swell from this cyclone are also measured. 
A cyclone at 08a 06h (Fig. 6-c and No. 9 in Fig. 7) caused the next rapid increase of periods from the end of the 9th. The arrival time of swell due to this cyclone was estimated as 09 d 0 th for the southern and 10d 01h for the northern coasts of Sorway (Table II), which also agree with the observed times. This eyclone approached with high velocity from the west (Fig. 6-d) and entered the Aretic Ocean on the 11th. It must be noticed that even by the passage of such a strong ayclone through Finland, no microseismic storm at either station was observed until it entered the Aretic O: ean. The estimates of arrival times of swell from the cyclones of $11 d 06 h$ and $12 d 06$ h to the roast (: (ryclone Tos. 10 and 11 in Fig. 7) also rearle up the cause of this

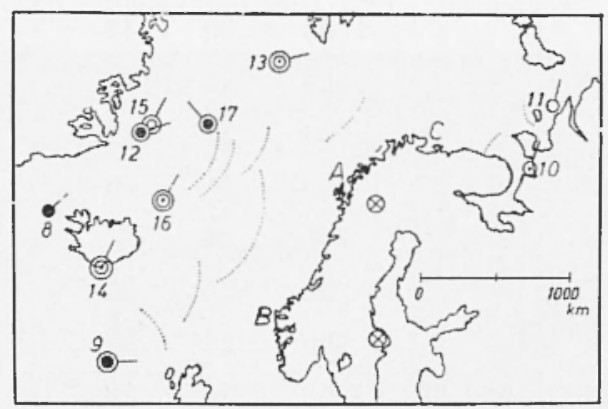

Fig. 7 - Positions of distant cyclones in December, 1957.

phenomenon. The calculated arrival times of swell become 11d $19 \mathrm{~h}$ and 13a 09h respectively, which correspond to the begimning and end of the period storn in question. Taking into account the rather small amplitudes at Uppsala, another small cyclone which ran near Kiruna from the 12th to the 13th (Fig. 6-d), would contribute to the sharp and isolated amplitude peak at Kiruna just at $12 \mathrm{~d} 12 \mathrm{~h}$.

A long-period microseismic storm to be expected from an intensive cyclone on the 10th off eastern coast of England (Fig. 6-(l), is rather obscured by a near cyclone around the calculated time of swell mrival.

A large microseisnic storm around the 17th at both stations is surely due to an intensive eyclone, passing off northern Scandinavia (Fig. 6-e). By sereral distant and intensive cyclones the periods of microseisms at both stations varied in phase with each other. The swell from the eyclone at $15 \mathrm{~d}$ 06h for instance (No. 12 in Fig. 7), reached the Norwegian coast around 16d 09h, which agrees well with the observations. 
The next cyclonic centers on the 19th and the 20th (Fig. 6-f and Nos. 14 and 15 in Fig. 7) are situated about $1100 \mathrm{~km}$ and $1300 \mathrm{~km}$ respectively from the nearest coast of Norway. From Table II, the arrival time of swell at the coast becomes $20 \mathrm{~d} 03 \mathrm{~h}$ and $21 \mathrm{~d} 0$ 5h respectively, which correspond to the beginning and peak of the amplitude and period storm on the 20 th.

A trial was made to see how the arrival time of swell is affected, if we assume that the most effective swell was delivered from the cyclonic center and not from the fringe of the cyclone (No. 15). In this case, the travelling path of swell to the coast (A) becomes $1300 \mathrm{~km}$. Then, the arrival time is calculated as 22d 01h. At this time, however, the observed period storm of microseisms had already ceased.

The next amplitude storm on the 23rd, which was remarkable at Kiruma, is due to the arrival of a cyclone from the 22 nd to the $23 \mathrm{rd}$ (Fig. 6-f). The simultaneous storm at Uppsala probably has the same origin as at Kiruna. The amplitude ratio Kiruna: Uppsala is about $1: 0.5$. The next peak on $26 \mathrm{~d} 12 \mathrm{~h}$ in both amplitude and period is surely produced by the swell which reached the Norwegian coast at that time from strong cyclonic centers on the 25th and the 26th respectively (Fig. 6-g and Nos. 16 and 17 in Fig. 7). The estimated arrival times of swell from the limits of the "eye" around these cyclonic centers at the Norwegian coast nearly correspond to the beginning and end of the observed period storm (Table II).

A cyclone approached the central Norwegian coast on the 29th and disappeared there. Maximum microseismic amplitudes at both stations a little later than the 29th are considered to be caused by this cyclone together with two other's, one near the coast of southern Norway and the other at the southern coast of White Sea. Being disturbed by the increase of microseismic amplitudes with shorter periods due to these cyclones, the period storm disappeared around the 29 th.

January, 1958.

In order to picture the extremely large microseismic storm on the 18th (as large as $12 \mu$ at Kiruna) within a certain limit, the scale of amplitudes in this month is further decreased to half of that of the preceding month. Till the 7 th, there were no disturbance sources around Scandinavia.

On the 7th, a cyclone (as strong as $955 \mathrm{mb}$ on the 7 th) lan through northern Furope (Fig. 8-a). But, as is always the case, such a situation 
has no remarkable effect upon the microseisms, not even at Uppsala. On the 10th, there were two cyclones off the northwestern coast of
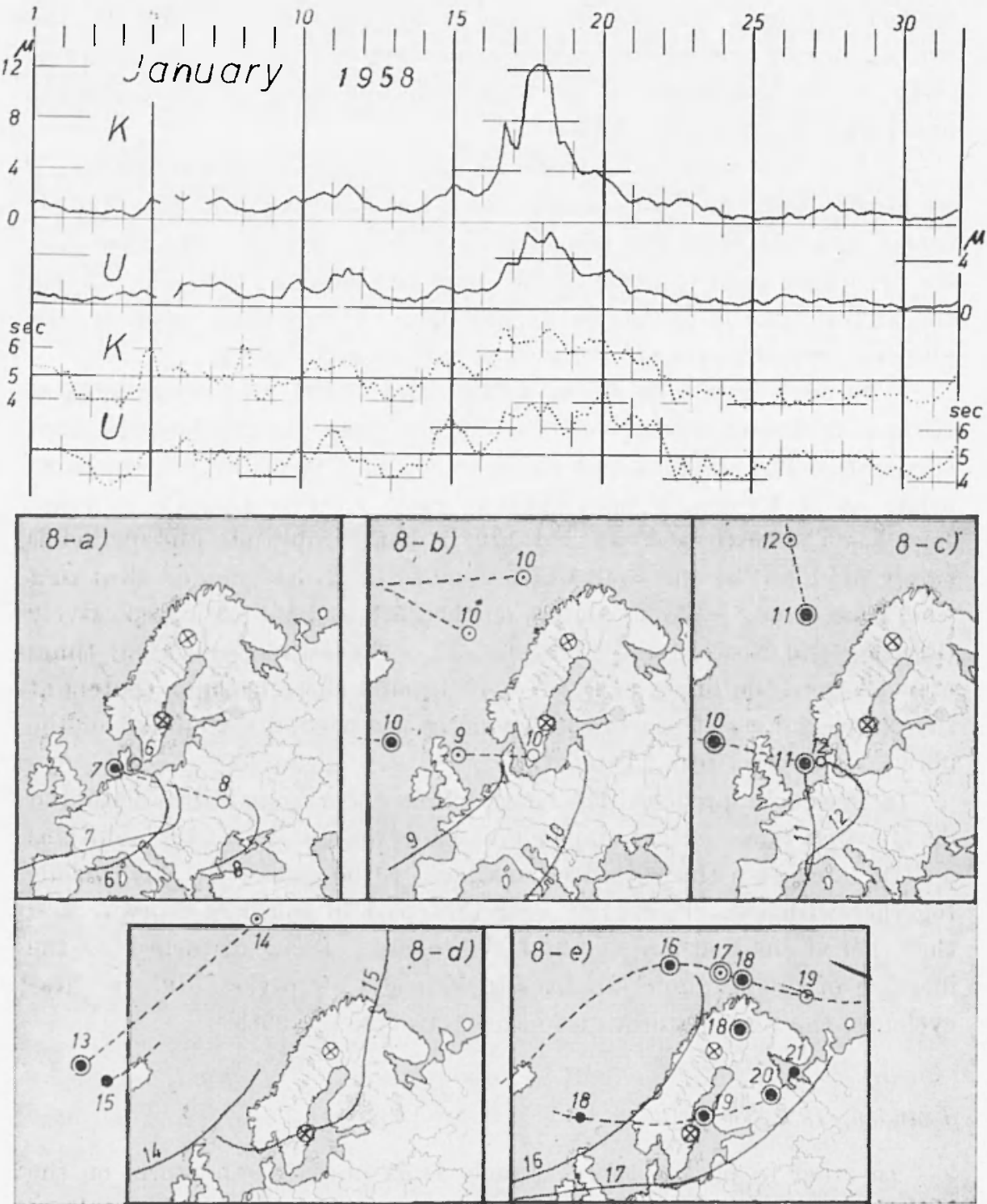

Fig. 8 - Amplitudes and periods of mieroseisms and weather situations in January, 1958.

Norway (Fig. 8-b). They wre combined on the 11th (Fig. 8-c) and then ran to the north. There were other intensive ones around Denmark 
during the same period (Fig. 8-b and -c). The microseismie storm at Uppsala with almost the same maximum amplitudes as at Kiruna around $11 \mathrm{~d} 12 \mathrm{~h}$, would result by the additive eflects of these strong cyclones.

An intensive cyclone ran far off Scandinalvia, as shown in Fig. 8-d. The maximum periods of microseisms at both stations on the 15th are caused by the swell from the fringe of the "eye" around the cyclonic center of the 13th (No. 18 in Fig. 9). The estimated swell arrival time becomes 14d 18h (Table III), which agrees quite well with the observed results.

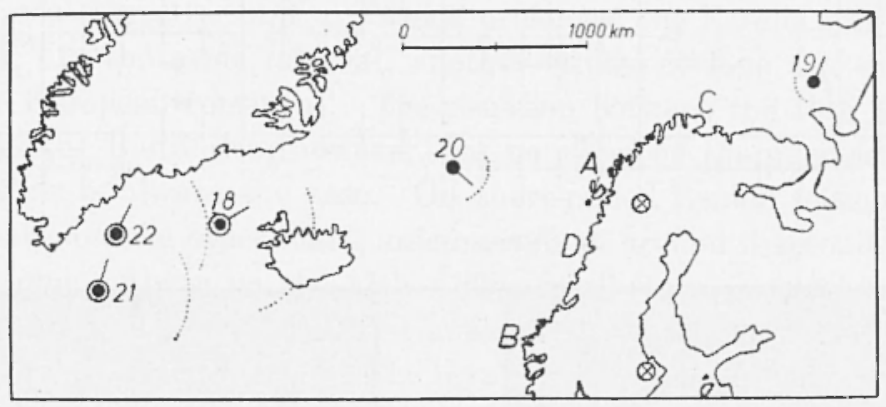

Fig. 9 - Positions of distant cyclones from January to April, 1958.

Another strong cyclone followed, as shown in Fig. 8-e. It had its minimum central pressure on the 17th and was divided into two, which caused the largest mieroseismic storm at Kiruna. Inother intensive ayclone inside northern Sweden on the 18th would have an additive effect to make such an extremely large storm at Kiruna. A little later, on the 19th, another strong cyclone ran eastward just over Uppsala. At the passage of this intensive cyclone over Uppsala a little before 19d $06 \mathrm{~h}$, the microseismic storm at Uppsala was already decreasing. It means that the storm at Uppsala in question was much more effected by the northern energy source than by the southern one.

The period storm of long duration, lasting until $22 \mathrm{~d} 00 \mathrm{~h}$, is explainad by swell due to the cyclone moving eastward over the Atlantic Ocean. But, as the locations of the cyclonic centers after the 19th were unknown, no verification of this suggestion was possible.

February, 1958.

As we have seen hitherto, the weather situation like the one of 03d 06h in Fig. 10-a with a cyclone around north Norway or still more? in north Russia, is very effective for microseismic storms. The same 
THTSt(0.A. $\therefore A N T()$
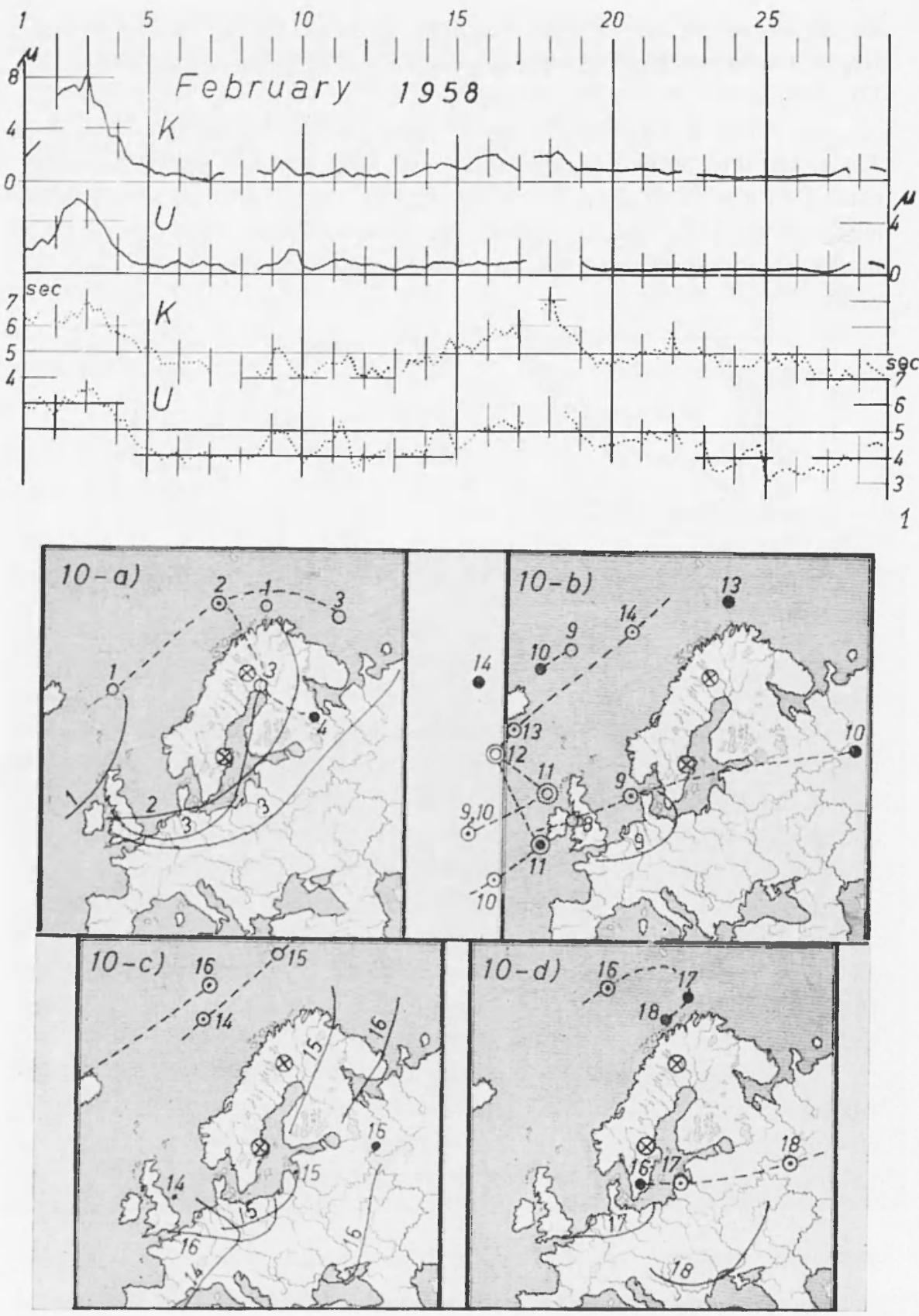

Pig. 10 - Amplitudes and periods of nicroseisms and weather sitnations in February, 1958. 
results were found by Båth (1952a). This situation resulted in a remarkable microseismic storm at both stations around the 3rd. Another dereloping eyclone approached the southern coast of Norway on the 9th (Fig. 10-b) and produced a little storm at Uppsala. Two much stronger cyclones approached on the 11th far out on the ocean west of England (Fig. 10-b). As they were mostly double, the corresponding swells disturber each other at the coast. Therefore, there is no remarkable microseismic period storm.

Two cyclones successively passed ofl the north-western coast of Scandinavia (Fig. 10-e and -d), which prolonged the Kirma storm until the 18th. In the same interval, another strong cyclone ran eastward over the European continent. The situation between the 16th and the 17th orer the Baltic Sea, however, has no effect on the microseisms at Uppsala, as is always the case. On short-period Benioff seismographs at Uppsala, on the other hand, microseisms of around 3 second period showed some activity on the 17th. This small storm would be caused by the passage of a cyclone over the southern Baltic Sea. The distant encrgy soure which increased the microseismic periods very gradually until fod 00h conld not be discovered on the weather map.

Mrerch, 19.58.

In this month the mirroseisms at the two stations were so small, that the average amplitudes were reduced to about $0.5 \mu$.

I cyclone approached the northern coast of Norway from west with high velocity (Fig. 11-a). This eyclone is related to the first storm of this month, around the 6th. At the same time, two ayclones appeared west and east of sonthern Seandinavia. The former increased in intensity on the 6 th at nearly the same position and then disappeared on the 7 th. These two cyclones on the 6 th on both sides of Uppsala may contribute to prolonging the storm at Uppsala more than at Kiruna.

Though not shown in the map there was a cyclone on the 11th and the 12 th $(990 \mathrm{mb}$ and $995 \mathrm{mb}$ respectively) over the south Baltic Sea. On the 13th and 14 th a cyclone $(995 \mathrm{mb}$ and $990 \mathrm{mb}$ respectively) appeared in eastern Europe. As always, these situations do not influence the microseisms very much, not even at Uppsala. On the other hand, the weak cold front (Fig. 11-b) from the 21st to 23 rd incereased the amplitudes at Kiruna. It shows again the strong eflect along northpron Sondinavian coast for the microseisms at Kirnan. 

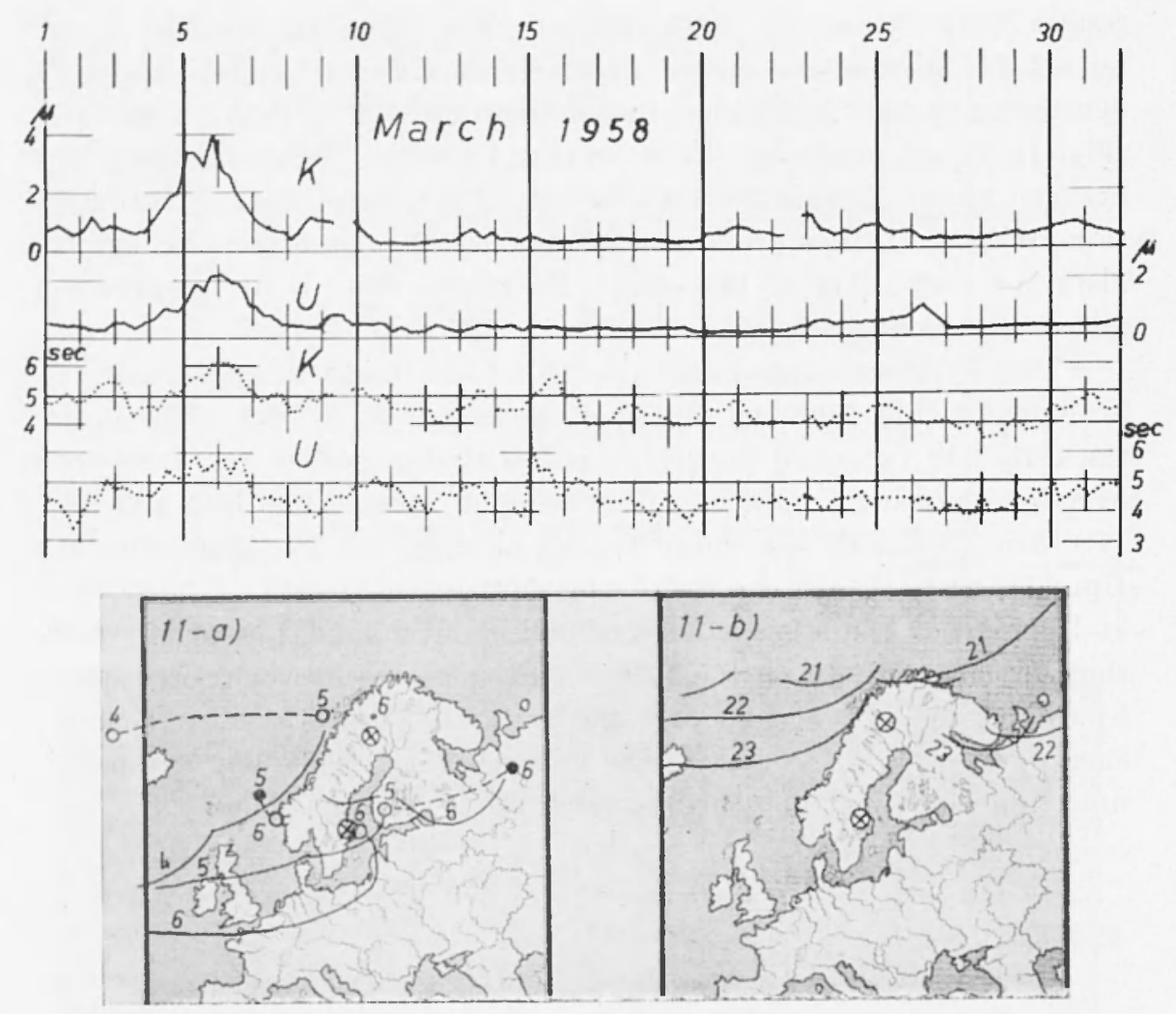

Fig. 11 - Amplitudes and periods of mieroseisms and weather situations in March, 1958.

April, 1958.

Till the 10th, weak cyclones (about $1000 \mathrm{mb}$ ) or cold fronts passed successively over the sea around Scandinavia. Due to them, many irregular variations appeared both in amplitude and period curves. For instance, due to the developing cyclone which entered the Arctic Ocean slightly after 07 d $06 \mathrm{~h}$ (Fig. 12-a), microseismic amplitudes at both stations began to increase from $06 \mathrm{~d}$ 12h. $\Lambda$ sharp period storm around $09 \mathrm{~d} 12 \mathrm{~h}$ might be caused by a cyclone at $08 \mathrm{~d} 06 \mathrm{~h}$ in the Arctic Ocean (Fig. 12-a and No. 19 in Fig. 9). This conclusion is ascertained by the estimate of arrival time of swell from the cyclone to the coast $\mathrm{C}$ (Table III). The calculated result of $09 \mathrm{~d} 07 \mathrm{~h}$ corresponds to the observed beginning of the period storm. The next increase of amplitudes at Kiruna on the 

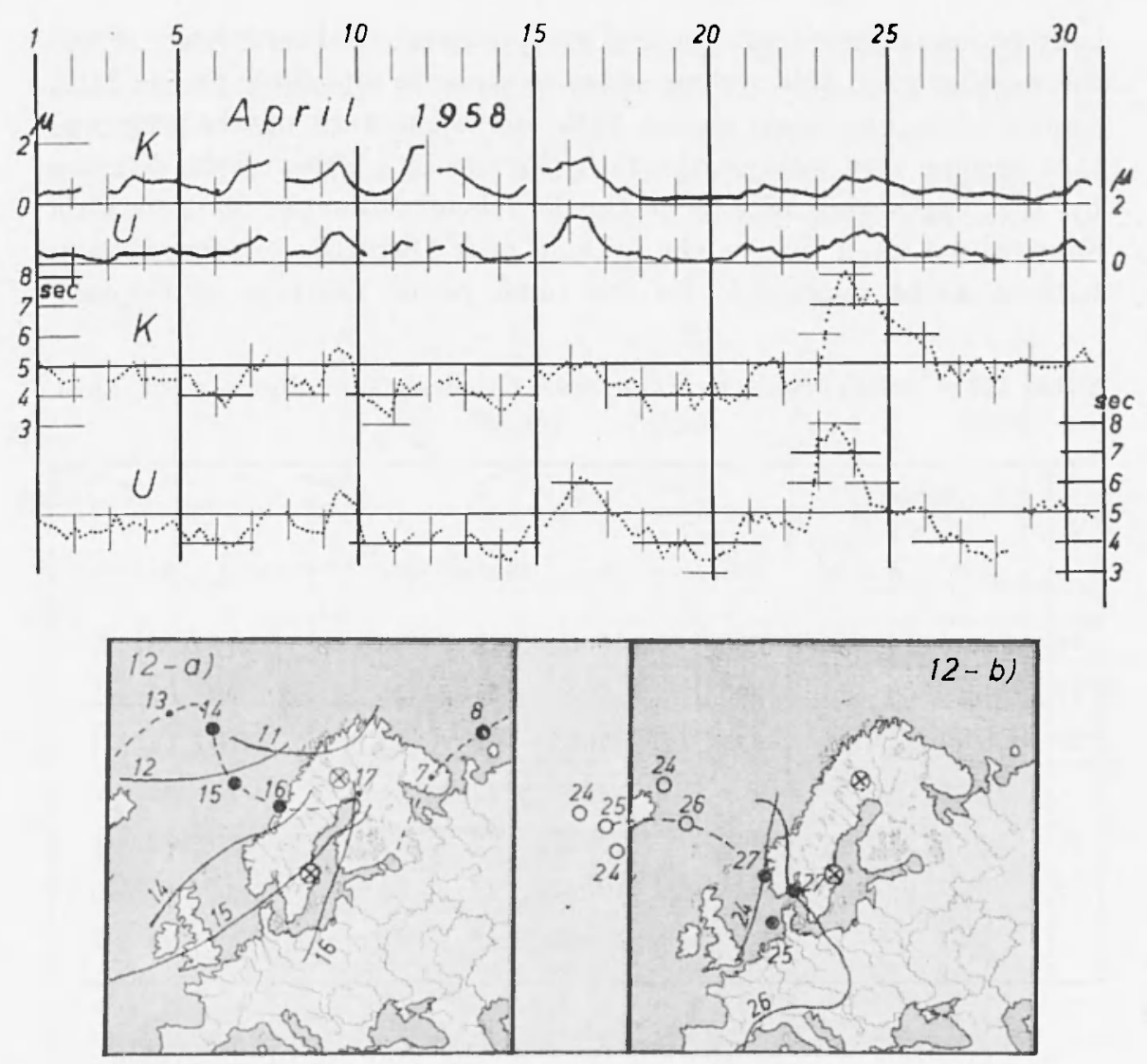

Fig. 12 - Amplitudes and periods of microseisms and weather situations in April, 1958.

12th was caused by a cold front, scratching the northern coast of Norway (Fig. 12-a). The following storm around the 16th both in amplitudes and periods can be explained by the approach of a moderate cyclone to the central Norwegian coast (Fig. 12-a). The arrival times of swell from the cyclone in its position at $14 \mathrm{~d} 06 \mathrm{~h}$ to the central (D) and to the southern coast (B) (No. 20 in Fig. 9) were estimated as $15 \mathrm{~d} 14 \mathrm{~h}$ and $15 \mathrm{~d} 23 \mathrm{~h}$ respectively (Table III). Both agree quite satisfactorily with the observational results.

An intensive cyclone appeared near the south-eastern coast of Greenland on the 21st. It moved a little northward on the next day (Nos. 21 and 22 in Fig. 9). It is also clear by the estimate of arrival times of swell from these two positions (Table III), that the extremely 
large perion increase from the $23 \mathrm{rd}$ was produced by this cyclone. From the weather map, this cyclone seems to separate into three on the 24 th, rombine into one again on the $25 \mathrm{th}$, move eastward on the 26 th and then become very weak on the 27 th (Fig. 12-b). The periorls decrease by the appearance of two or three cyclones from the 23ril to 25th. Short-periorl swell due to the cyclone near Denmark on the 25th is without doubt responsible for the rapir period decrease at Uppsalia.

Table III - Lstmaten arrival times of swells - (January to April, $1958)$

\begin{tabular}{|c|c|c|c|c|c|c|c|c|c|c|}
\hline \multirow[t]{2}{*}{ N. } & \multicolumn{3}{|c|}{$\begin{array}{l}\text { Date } \\
\text { GHTT }\end{array}$} & \multirow{2}{*}{$\begin{array}{c}p_{o} \\
m b\end{array}$} & $\because \quad \cdot I$ & & & \multicolumn{2}{|c|}{$T$} & \multirow[t]{2}{*}{ C } \\
\hline & & d & h & & $\mathrm{km}$ & $\mathrm{km} / \mathrm{hr}$ & $\ln r$ & d1 & h & \\
\hline 18 & Jan. & 13 & 06 & 965 & 1000 & 28 & 36 & 14 & 18 & B \\
\hline 19 & Apr. & 08 & 06 & 990 & 600 & 24 & 25 & 09 & 07 & C \\
\hline 20 & $"$ & 14 & 06 & 995 & 700 & 22 & 32 & 15 & 14 & D \\
\hline & & & & & 900 & 22 & +1 & 15 & 23 & A \\
\hline 21 & $n$ & 21 & 06 & 965 & 1400 & 32 & 44 & 23 & 02 & B \\
\hline 22 & $n$ & 22 & 06 & 965 & 1700 & 32 & 53 & 24 & 11 & A \\
\hline & & & & & 1400 & 32 & 44 & 24 & 02 & B \\
\hline
\end{tabular}

It must be noticed that in spite of the approach of a cyclone to the southern coast of Norway on the 27th, there is practically no microseismic storm at Uppsala.

Ma!y, 19.58.

As the ampliturles of microseisms became rather small in this month, the ampliturle scale is enlarged to twice that of the preceding months. As shown in Fig. 13-a, a cyclone reached the western coast of Scandinavia on the 9 th. The cyclone stayed nearly in the same position with decreasing intensity. $\Lambda$ cold front moved across south Scandinavia from the 9 th to 10th. Jurging from the time of beginning of the microseismic storm from $10 \mathrm{~d}$ 00h, the cold front is likely to prorluce the storm. But, it is difficult to explain why ampliturles had begun to decrease from $11 \mathrm{~h} 12 \mathrm{~h}$ despite the fact that the cyclone was keeping its intensity until 12 d $06 \mathrm{~h}$ at least. 
A peak which appeared only at Uppsala about 201 12h might be produced at the south Norwegian coast by the cyclone in its situation of 20 d $06 \mathrm{~h}$ (No. 23 in Fig. 14). The arrival time of swell from this position of the cyclone to the nearest southern coast of Sorway was estimated as $201 \mathrm{l} 15 \mathrm{~h}$ (Table IV), which agrees quite well with the observations.
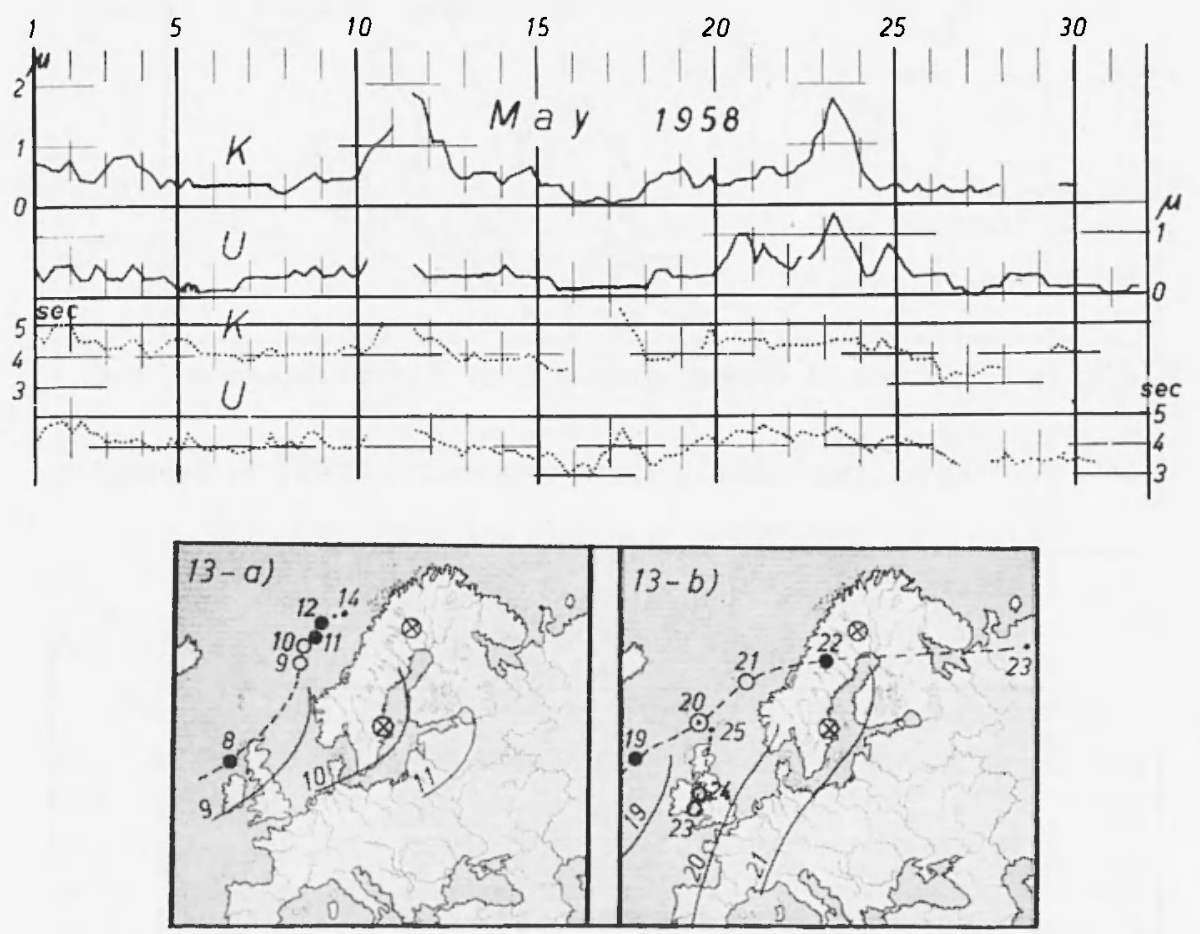

Fig. 13 - Amplitudes and periods of microseisms and weather sitnations in May, 1958.

A slarp amplitude storm at both stations at $23 \mathrm{~d}$ 06h is certainly caused by swell arriving at the northern coast from the ayclone on the 21st (No. 24 in Fig. 14). The arrival time of swell at the coast $(\lambda)$ is estimated as 231 05h (Table IV), which agrees with observations. The relocity of the cyclone from the 19 th to 20 th and from the 20 th to $21 \mathrm{st}$ is calculated as $33 \mathrm{~km} / \mathrm{hr}$ and $32 \mathrm{~km} / \mathrm{hr}$ respectively, i.e. much higher than the estimated swell velocity (see also Table IV). For this reason, the short-period swell from the cyelonic positions nearer to the 
coast reaches the coast earlier than the long-period swell from the distant positions. Therefore, there are no long-period microseisms in this case.

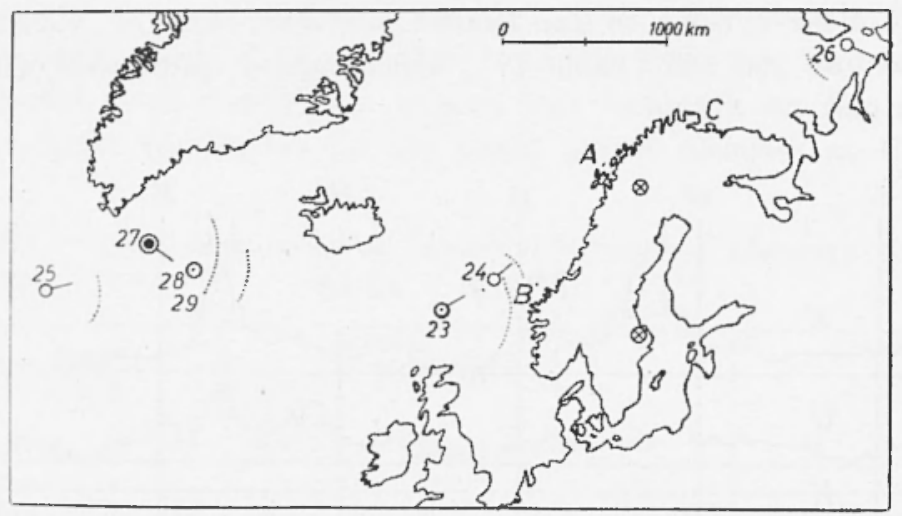

Fig. 14 - Positions of distant cyclones from May to September, 1958.

Table IV - Estimated arrival Times of swells - (May to September, 1958).

\begin{tabular}{|c|c|c|c|c|c|c|c|c|c|c|}
\hline N. & & $\begin{array}{c}\text { ate } \\
\text { MT } \\
\text { il }\end{array}$ & h & $\begin{array}{r}p_{0} \\
m b\end{array}$ & $\begin{array}{c}D-D_{c} \\
\mathrm{~km}\end{array}$ & $\begin{array}{c}v \\
\mathrm{~km} / \mathrm{hr}\end{array}$ & $\begin{array}{r}l \\
\operatorname{lir}\end{array}$ & & $\mathrm{h}$ & C \\
\hline 23 & May & 20 & 06 & 975 & 150 & 17 & 09 & 20 & 15 & B \\
\hline 24 & $"$ & 21 & 06 & 985 & 800 & 17 & 47 & 23 & 05 & $A$ \\
\hline 25 & June & 11 & 06 & 985 & 2400 & 26 & 92 & 15 & 02 & B \\
\hline 26 & Sept. & 08 & 06 & 980 & 700 & 22 & 32 & 09 & 14 & C \\
\hline 27 & ” & 17 & 06 & 960 & 1600 & 24 & 67 & 20 & 01 & B \\
\hline 28 & $"$ & 18 & 06 & 970 & 1300 & 24 & 54 & 20 & 12 & B \\
\hline 29 & $"$ & 19 & 06 & 965 & 1300 & 24 & 54 & 21 & 12 & B \\
\hline
\end{tabular}

June, 1958 .

In this month, microseismic activity was poor and there are some interruptions at Kiruna. The weather situation related to a remarkable period increase between the 14th and 18th, is the only one of interest.

This period storn resulted from the appearance of a cyclone about $600 \mathrm{~km}$ off the southern coast of Greenland on the 11th (No. 25 in 
Fig. 14). The arrival time of swell from this cyclone at the nearest Norwegian coast (B) is given in Table IV. The result, $15 \mathrm{~d} 02 \mathrm{~h}$, corresponds to the time of the largest period observed. Furthermore, the cyclone gradually approached with decreasing energy the southern coast of Iceland $(985 \mathrm{mb}, 995 \mathrm{mb}, 990 \mathrm{mb}$ and $995 \mathrm{mb}$ on the 12th, 13th, 14th and 15th respectively). This approach and energy decrease caused a gradual decrease of microseismic periods.

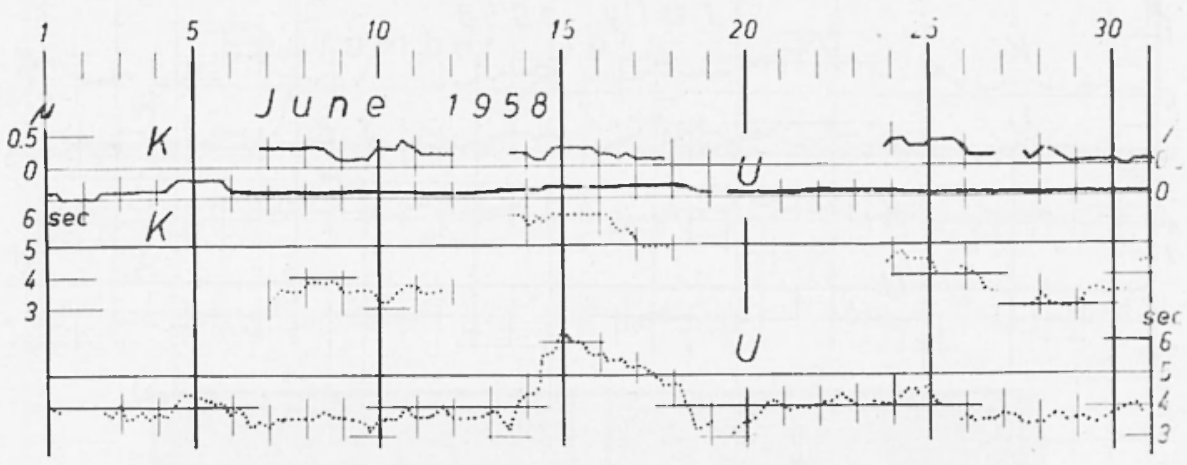

Fig. 15 - Amplitudes and periods of microseisms in June, 1958.

July, 1958.

The first microseismic storm of which a small peak appeared about 10d $12 \mathrm{~h}$ can be connected with a cyclone passing through the northern part of Scandinavia from the 10th to 11th (Fig. 16-a). This cyclone was divided into two on the 12th near the northern coast of Norway, which prolonged the microseismic storm. The passage of a smaller cyclone from the 8th to 9 th also seems to have some effect upon the microseismic amplitudes at Kiruna. Another cyclone ran through Scandinavia (Fig. 16-b). It must be noticed that the peak of the amplitude curve at Uppsala due to this source occurred when the cyclone reached near north-eastern part of Scandinavia.

Very small cyclones (central pressure higher than $1000 \mathrm{mb}$ ) successively passed over and around Scandinavia in this month. But, they did not have much effect on the microseisms at the two stations.

As to the remarkable storm which occurred only at Kiruna about $26 \mathrm{~d} 12 \mathrm{~h}$, the general explanation from the intensity or the movement of a cyclone only is impossible. The only indication the writer could find from the meteorological data was a small cyclone $(1005 \mathrm{mb})$ very near Kiruna at $26 \mathrm{~d} 06 \mathrm{~h}$ and that the greatest wind velocity was measur- 
ed at the northermmost roast of Norway just at that time. Therefore, this microseismic: storm was caused by such local meteorological conditions, which were missing in weather maps of once a day.

As there is nothing to sav about microseisms in the next month. it is omitted.
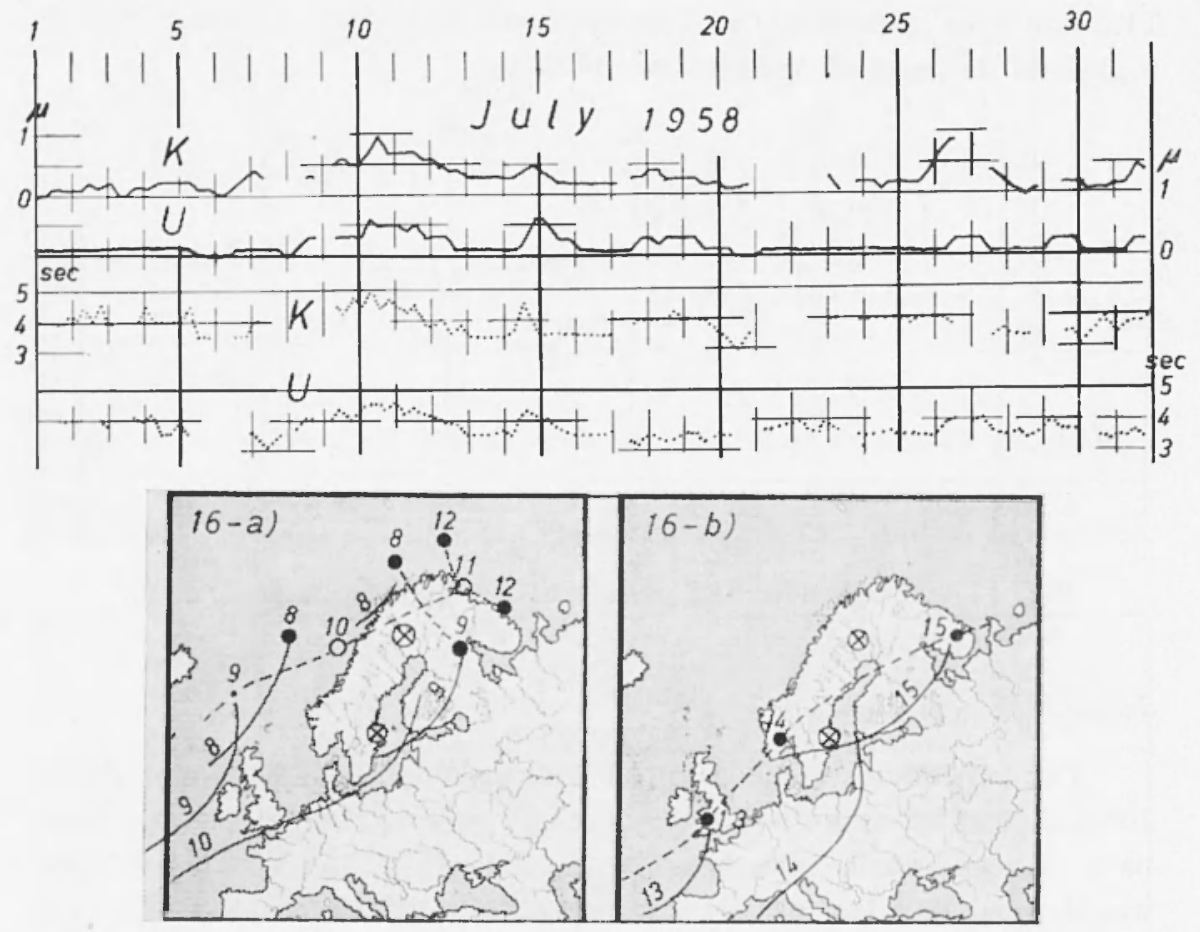

Fig. 16 - Amplitudes and periods of microseisms and weather situations in $\mathrm{Jul}_{y}, 1958$.

September, 19:58.

The first stome occurring from the 7 the is surely due to the passage of a developing cyclone far of the northern coast of Scanclinavia (Fig. 17-a). There is also a parallel period increase at both stations. The microseisms of about 5.5 second period alound 090 ooh are aused by the swell from the exclone at some stage from o7d o6h to 08 d 06 h. For instance, the arrival time of swell from the cyclone at its later stage at 08 d $06 \mathrm{~h}$ (No. $26 \mathrm{in} \mathrm{Fig.} \mathrm{14)} \mathrm{at} \mathrm{the} \mathrm{northern} \mathrm{coast} \mathrm{of} \mathrm{Scantinavia} \mathrm{(C)}$ was estimated to be 09d 1 th (Table IV), which nearly corresponds to the end of the period storm. 
From the 11th to the 12th, a cyclone of decreasing intensity and a cold front passed across northern Scandinavia (Fig. 17-a). Perlaps, berause of the decreasing energy, the effect upon microseisms is very poor. However, a larger eyclone follows with high velocity off the north(astern coast of Scandinavia (Fig. 17-b). The time lag of the peak of
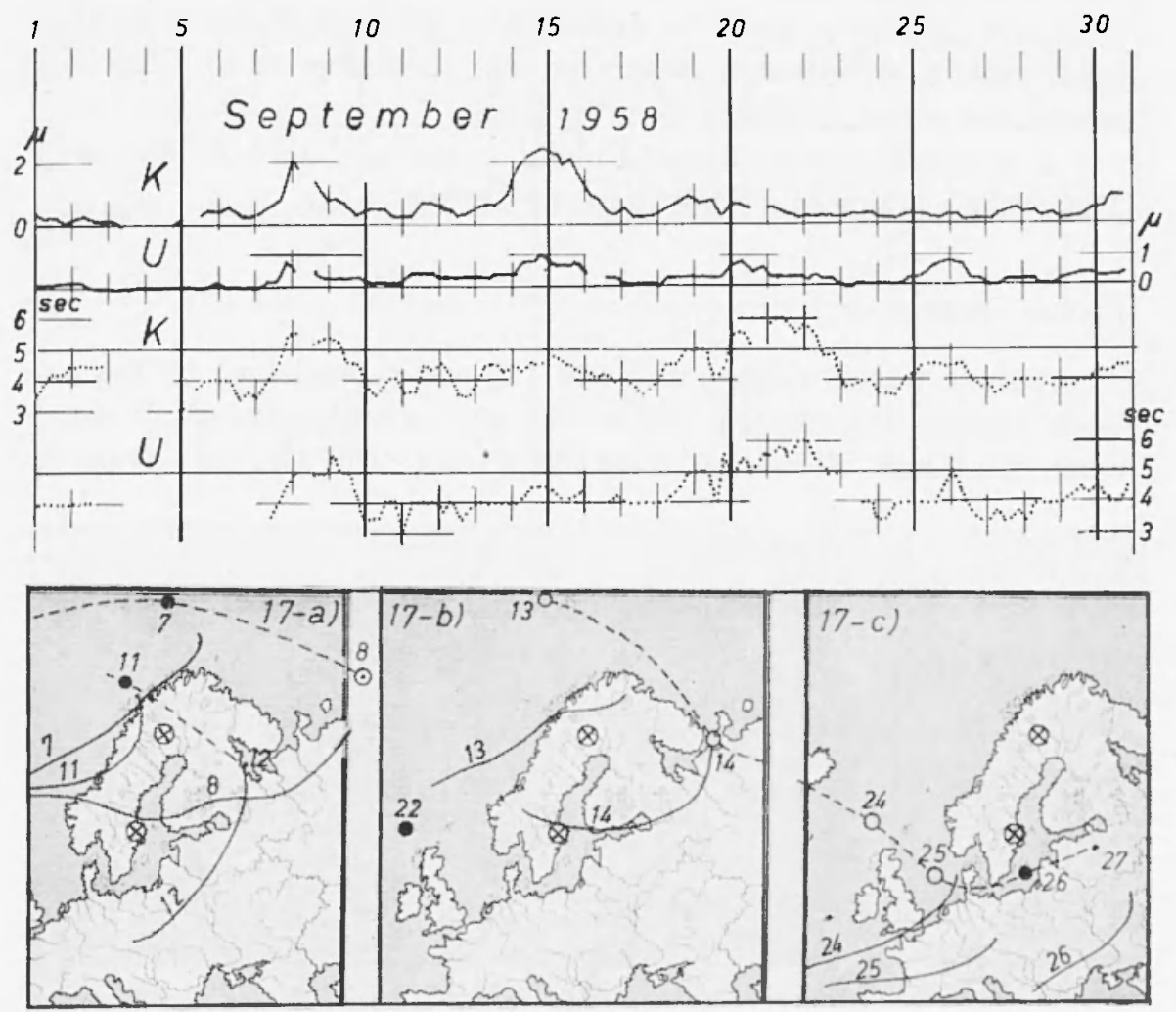

Fis. 17 - Amplitudes and periods of mieroseisms and weather situations in september, 1958.

amplitudes around 15 d $00 \mathrm{~h}$ is too large to be explained by the travelling relocity of this eyclone. The only meteorological data which can explain this, is the wind velocity at the northermmost coast which reached its maximum at 15 d 06h. Therefore, the storm might be caused by a local phenomenon at that coast. In intensive exclone appeared between Greenland and Iceland on the 17th, which moved till the 22nd around the same position with nearly the same intensity (Nos. 27, 28 
and 29 in Fig. 14). Arrival times of swell from the fringes of "eye" around the cyclonic centers at each position are given in Tabe IV. The results cover the earlier part of the period storm observed. The cyclone moved slowly towards England and reached about $500 \mathrm{~km}$ off the southern coast of Iceland with decreasing energy $(975 \mathrm{mb}$ and $980 \mathrm{mb}$ on the 20 th and 21st respectively). The long-period swell from the cyclones on these days, however, would be disturbed by the appearance of another small cyclone off northern Britain on the 22nd (Fig. 17-b). For this reason, the period decreased from the 22 nd.

$\Lambda$ moderate cyclone followed along a path as shown in Fig. 17-c. This cyclone produced a small storm at Uppsala.

October, 1958.

A small period maximum at $07 \mathrm{~d} 12 \mathrm{~h}$ can be explained by the cyclone around 04d $06 \mathrm{~h}$ (No. 30 in Fig. 19), of which the swell could reach the south Norwegian coast $(B)$ arbund $07 \mathrm{~d} 03 \mathrm{~h}$, as given in

Table V - Lstimated arrival times of strells - (October, 1958).

\begin{tabular}{|c|c|c|c|c|c|c|c|c|c|c|}
\hline N. & & $\begin{array}{c}\text { ate } \\
\mathrm{M}^{\prime} \mathrm{T} \\
\mathbf{d}\end{array}$ & $\mathrm{h}$ & $\begin{array}{l}p_{o} \\
m b\end{array}$ & $\begin{array}{c}D-I \\
\mathrm{~km}\end{array}$ & $\begin{array}{c}v \\
\mathrm{~km} / \mathrm{hr}\end{array}$ & $\begin{array}{l}t \\
\ln r\end{array}$ & \multicolumn{2}{|c|}{$T$} & C \\
\hline 30 & Oct. & 04 & 06 & 980 & 1800 & 26 & 69 & 07 & 03 & B \\
\hline 31 & $"$ & 08 & 06 & 975 & 1500 & 28 & 54 & 10 & 12 & 13 \\
\hline & & & & & 1000 & 26 & 38 & 09 & 20 & B \\
\hline 32 & " & 09 & 06 & 975 & 1000 & 30 & 33 & 10 & 15 & A \\
\hline & & & & & 700 & 30 & 23 & 10 & 05 & B \\
\hline 33 & $n$ & 14 & 06 & 980 & 1600 & 30 & 53 & 16 & 11 & B \\
\hline 34 & " & 15 & 06 & 985 & 1200 & 30 & 40 & 16 & 22 & B \\
\hline 35 & $"$ & 17 & 06 & 975 & 2100 & 26 & 81 & 20 & 15 & B \\
\hline 30 & $n$ & 18 & 06 & 990 & 1600 & 26 & 62 & 20 & 20 & B \\
\hline
\end{tabular}

Table V. This result agrees quite well with the observations. As another cyclone $\left(p_{o}=990 \mathrm{mb}\right.$ ) appeared on $05 \mathrm{~d} 06 \mathrm{~h}$ about $600 \mathrm{~km}$ off the western coast of south Norway, the period of microseisms decreased quickly, because the swell was disturbed by the near source. 
Both amplitudes and periods at the two stations increased from about the 9 th with their peaks nearly at $10 \mathrm{~d}$ 12h. There were two cyclones on the 7th, which combined into one on the 8th (Fig. 18-a).
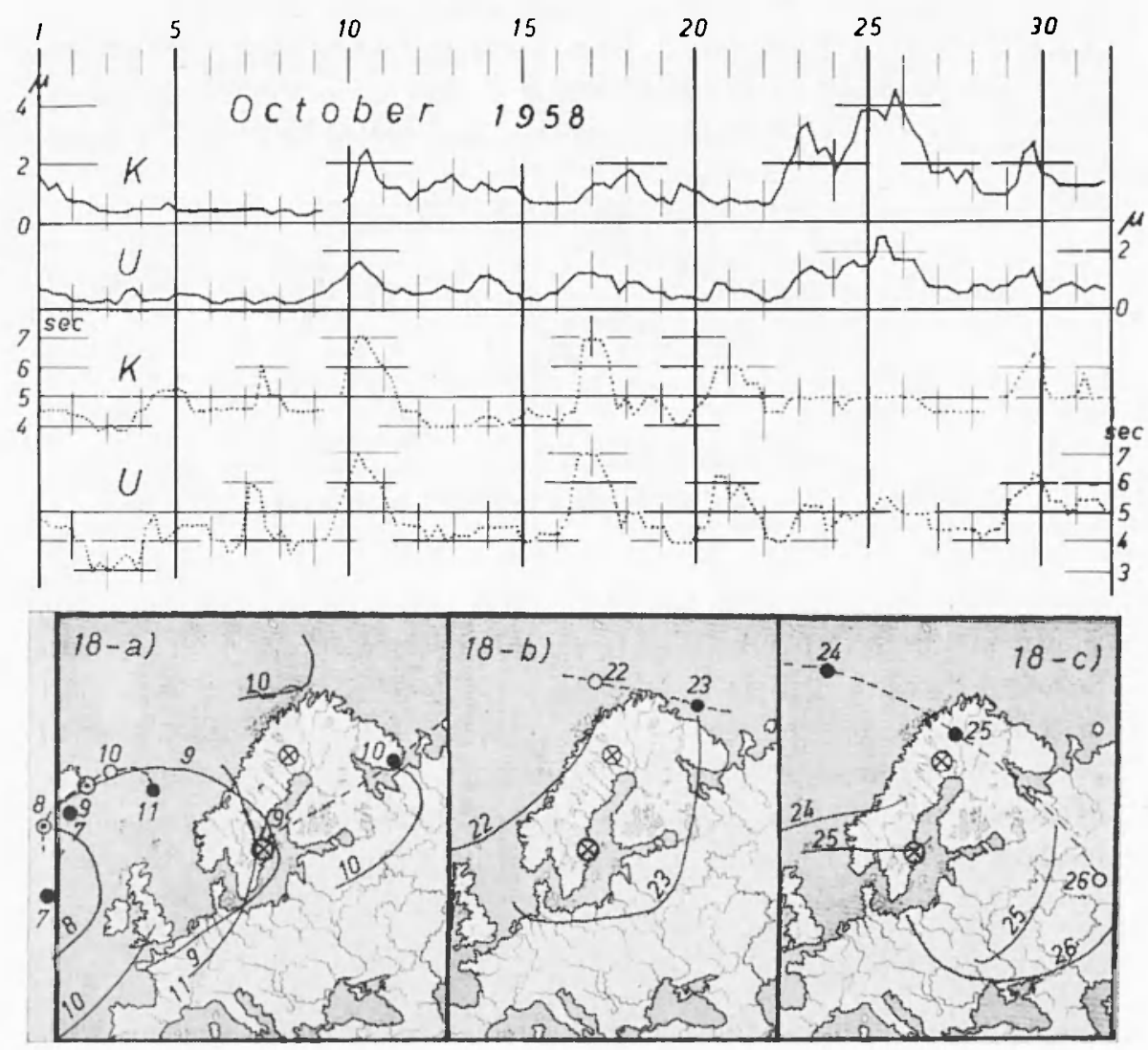

Fig. 18 - Amplitudes and periods of microseisms and weather situations in Octoher, 1958.

The microseismic storm is probably caused by the single cyclone near Iceland in its situations of $08 \mathrm{~d} 06 \mathrm{~h}$ and $09 \mathrm{~d} 06 \mathrm{~h}$ (Fig. 18-a and Nos. 31 and 32 in Fig. 19). Arrival times of swell at southern (B) and northern (A) coasts of Norway were estimated separately (Table V). These times correspond to the beginning and peak of the period storm.

There was another cyclone near the coast of Iceland during the 14th to 15th and from the 17th to 18th. As shown in Table V, the swells from these cyclones (Nos. $33,34,35$ and 36 in Fig. 19) are found 
to reach the Norwegian coast just around the 17 th and 21 st respectively, both in agreement with observations.

An incerase of amplitures from the 23 rd, especially remarkable at Kirma, is undoubtedly due to a cychone which passed along the northern coast of Norway (Fig. 18-b). There was a distant eyclone near the coast of Greenland on the 21st (nearly in the same position as No. 30 in Fig. 19). The swell from this cyclone is expecterl to cause a remark-

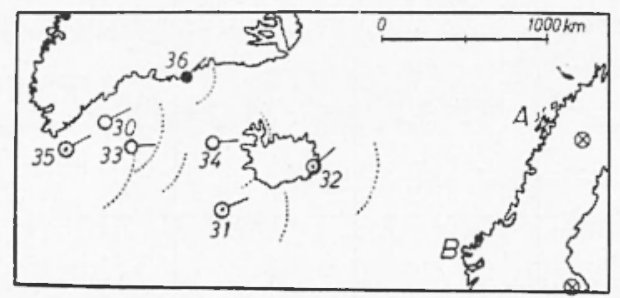

Fir. 19 - Positions of distant cyclones in October, 1958.

able period storm around the 2 th. But this was not the rase. Is shown in the next figure (Fig. 18-c), this ayclone approached northern Soandinavia with a high volocity and hat reached the northern coast of Norway alrearly before the $25 \mathrm{th}$, i.e. before the arrival of long-period swell. Therefore, the long-period but small-dmplitude swell from the cyclone in its situation on the 21 st was effectively maskerd by the swell of short period but large amplitude from its situation on the 25 th.

November, 19:58.

In this month, Scandinavia was surromded by many eyclones with rentral pressures lower than 1000 mb. Such a circeumstance made the microseismire amplitures at both stations always high. Therefore, the amplitude seale (Fig. 20) was agrain reduced to half of those in the precerding month. The periods also rose to aromed five seconds in average.

I cyclone with decreasing intensity apperoached the midrle Norwegian coast on the 3rd (Fig. 20-a). However, it produced no obvious microseismice elfect.

There was a surden increase of periods somewhat after the 13 th. A single distant ryclone appeared between Greenland and Iceland on the 11th (No. 37 in Figr. 21). The estimated arrival time of swell from this eyclone coincirles with the time of this rapir period inerease 
(Table VI). The next increase of mucroseismic periods, at $16 \mathrm{~d} 00 \mathrm{~h}$, corresponds to the arrival time of swell at the south Norwegian coast (B) from a single cyclone at 131 06h (No. 38 in Fig. 21 and Table VI).
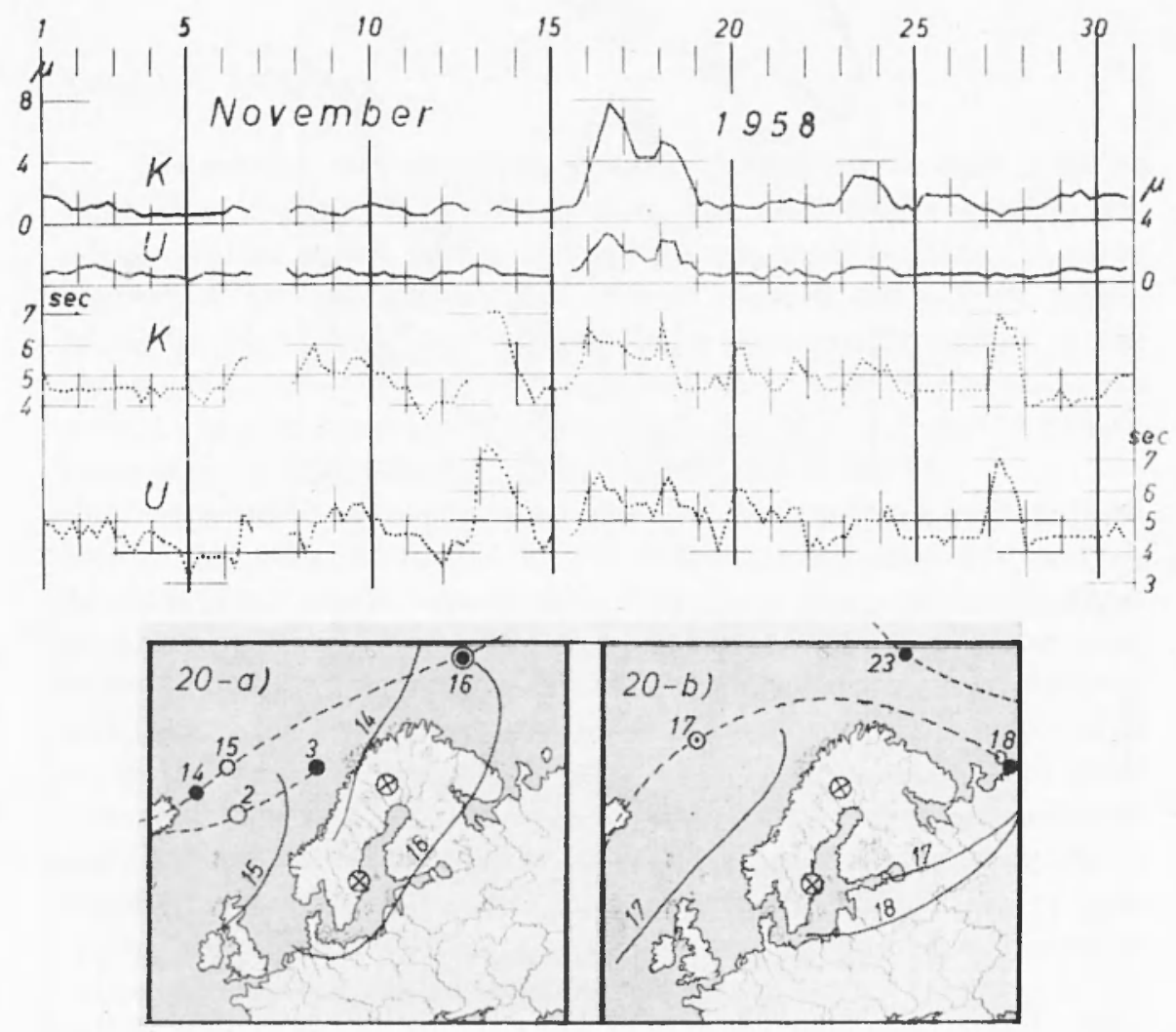

Fig. 20 - Amplitudes and periods of microsejsms and weather situations in November, 1958.

It crossed Iceland and moved outside the norther'n roast of Norway (Fig. 20-a), causing a large amplitude storm at $16 \mathrm{~d}$ 12h. By the approach of this cyclone to the northern coast, the periods of niceoseisms decreased a little.

Another cyclone followed with decereasing intensity along a path as shown in Fig. 20-b. This produced the next peak on the 18th. Judging from the sinnilar anplitude variation from the 16 th to 19 th at both stations, the microseisms at both stations secent to have the same origin 
somewhere along the northermnost coast. The ampliturle ratio Kiruna: Uppsala is approxinately $1: 0.5$.

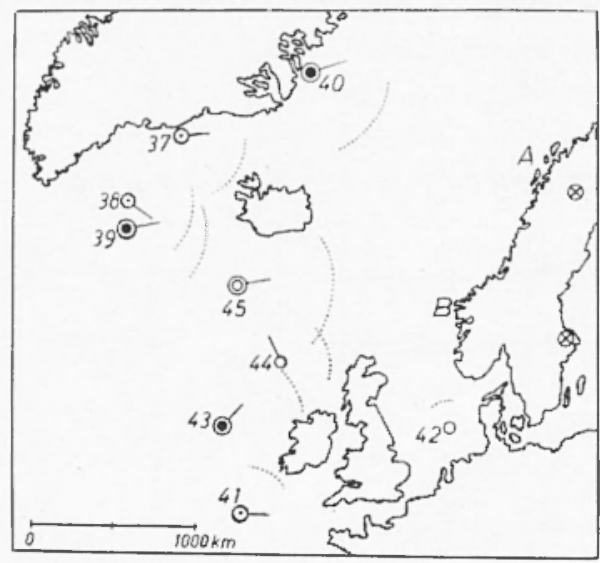

Fig. 21 - Positions of distant cyclones from November to December, 1958.

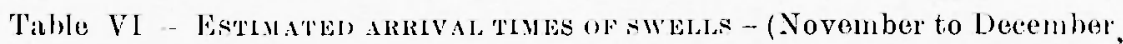
(958).

\begin{tabular}{|c|c|c|c|c|c|c|c|c|c|c|}
\hline N. & \multicolumn{3}{|c|}{$\begin{array}{l}\text { 1)ate } \\
\text { G.MT }\end{array}$} & $\begin{array}{l}p_{0} \\
m b\end{array}$ & \multicolumn{2}{|c|}{$\begin{array}{l}D \cdot D_{0} \quad v \\
\mathrm{~km} \quad \mathrm{~km} / \mathrm{hr}\end{array}$} & $\begin{array}{l}\text { t } \\
\mathrm{hr}\end{array}$ & \multicolumn{2}{|c|}{$T$} & C \\
\hline 37 & Nor. & 11 & 06 & 975 & 1400 & 30 & 47 & 13 & 05 & B3 \\
\hline 38 & $"$ & 13 & 66 & 970 & 1600 & 24 & $6 i 7$ & $16 i$ & 01 & B \\
\hline 39 & $"$ & 25 & 06 & $9(65)$ & $1+00)$ & 30 & +7 & 27 & 0.5 & B3 \\
\hline 40 & Iee. & 013 & 06 & 965 & 900 & 30 & 30 & 04 & 12 & il \\
\hline \multirow[t]{2}{*}{41} & $"$ & 16 & 06 & 970 & 2300 & 30 & 77 & 19 & II & $\lambda$ \\
\hline & & & & & 1300 & 30 & +3 & 18 & (1) & B \\
\hline \multirow[t]{2}{*}{42} & $"$ & 17 & 06 & 98.5 & 1600 & 20 & 80 & 20 & 14 & $\Lambda$ \\
\hline & & & & & 500 & 20 & 25 & 18 & 07 & I3 \\
\hline \multirow[t]{2}{*}{43} & $"$ & 21 & $06 \mathrm{i}$ & $96(i 5)$ & 19000 & 37 & 51 & 23 & 09 & $\lambda$ \\
\hline & & & & & 1100 & 30 & 37 & 22 & 19 & B \\
\hline \multirow[t]{2}{*}{44} & $"$ & 22 & 06 & 980 & $1+00$ & 37 & 38 & 23 & 20 & $A$ \\
\hline & & & & & 700 & 30 & 23 & $2: 3$ & ()5 & B \\
\hline \multirow[t]{2}{*}{45} & " & 28 & 06 & 950 & 1200 & 37 & 32 & 29 & 14 & A \\
\hline & & & & & 700 & 37 & 19 & 29 & (1) & B \\
\hline
\end{tabular}


As seen in Table VI, the last rapid increase of microseismic periods on the 27 th is caused by the single distant cyclone at $25 \mathrm{~d} 06 \mathrm{~h}$ off the eastern coast of Greenland (No. 39 in Fig. 21).

December, 1958 .

The general meteorological conditions in this month were quite the same as in November, i.e. Scandinavia had continuously small microseismic storms caused by the successive passages of cyclones. A great increase of periods from the 3rd at both stations and a great microseismic storm with its peak on the 5th are undoubtedly related to the passage of an intensive cyclone, as shown in Fig. 22-a. The period storm around $04 d$ 12h coincides with the arrival time of swell from the cyclone in its stage of 03d 06h (No. 40 in Fig. 21 and Table VI).

There were successive strong and distant cyclones over the ocean between Iceland and Britain from the 10th to the 23rd (Fig. 22-b and -c). As there were simultaneously other distant or near cyclones in these days, except for the 16th, 21st and 22nd, microseismic period storms, to be expected from distant and intensive cyclones, appeared only in such favourable days when swell from the single distant cyclone could reach the coast without being disturbed by other swell due to other cyclones. The locations of cyclones with such favourable conditions are shown in Fig. 21 by Nos. 41, 43 and 44, and the estimated arrival times of swells at the Norwegian coast are given in Table VI. From these results, we understand that the two sharp increases of microseismic periods around $19 \mathrm{~d} 00 \mathrm{~h}$ and $23 \mathrm{~d} 06 \mathrm{~h}$ are caused by the swell due to the energy sources at $16 \mathrm{~d} 06 \mathrm{~h}$ and $21 \mathrm{~d} 06 \mathrm{~h}$ or $22 \mathrm{~d} 06 \mathrm{~h}$, respectively. The estimated arrival time of swell (18d 01h) from the energy source 41 to the south Norwegian coast (B), taking a slightly curved path into account, is earlier than observed. This is explained by the existence of another cyclone between England and Denmark at $17 \mathrm{~d} 06 \mathrm{~h}$ (see Fig. 22-b and No. 42 in Fig. 21). The estimated arrival time of swell from this cyclone to the southern coast (B) becomes $18 \mathrm{~d} 07 \mathrm{~h}$, which is nearly the same as for cyclone 43. Therefore, long-period swell from No. 43 would be disturbed by short-period swell from No. 42 at the southern coast. This condition does not appear at the northern coast (A). As shown in Table VI, the arrival times of swell from the two sources are $19 \mathrm{~d}$ $11 \mathrm{~h}$ and $20 \mathrm{~d} 14 \mathrm{~h}$ respectively, which are sufficiently different from each other. 

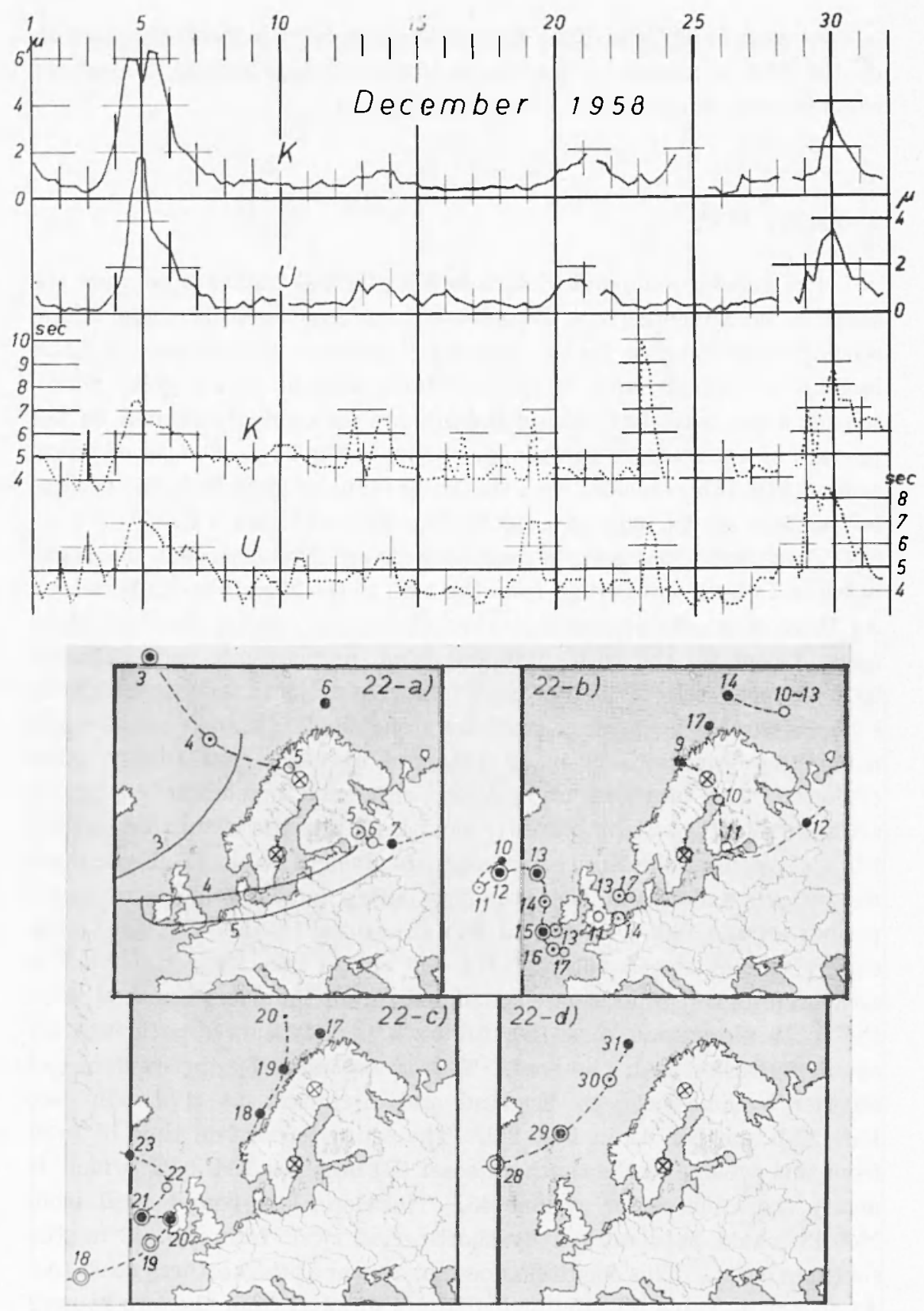

Fig. 22 - Amplitudes and periods of microseisms and weather situations in December, 1958. 


\section{DISCUSSTON AND CONCLUSTONS.}

Through the comparative studies of the time variations of microseismic amplitudes and periods at Kiruna and Uppsala, Sweden, and the weather situations around Scandinavia in every month during I.G.Y., the following conclusions can be drawn.

a) As cyclones and the accompanying cold fronts often pass the coasts of Scandinavia nearly at the same time, it is often difficult to decirle whether a certain microseismic storm is due to the passage of a cyclone or a cold front, without using more continuous observations. But, in a few favourable cases, it was found that cold fronts are the origin of microseisms.

b) The northern coast of Norway gives comparatively stronger microseismic storms at Kiruna than the southern coast does at Uppsala. Microseismic storms originating at the northern coast of Scandinavia show parallel variations of ampliturles at Kiruna and Uppsala, but the amplitude ratio of Kiruna: Uppsala is usually close to $2: 1$.

This amplitude latio is just what should be expected for distribution of microseismic waves over a homogeneous structure (Båth $1951 \mathrm{~b}$ ). However, this distribution is risturbed by inhomogeneities in the crustal structure, mainly by the mountainous region along the Scandinavian peninsula. This has been pointed out especially by Russian seismologists, e.g. Prosvimin, Proskuriakova, Rykhunov and Savarensky (1959) and Rykhunov and Mishin (1962).

An example showing the poor transmission of microseismic waves, especially of short period, is the following. On March 31st, 1962, a cyclone $\left(p_{o}-980 \mathrm{mb}\right)$ arrived just at the southernmost edge of Sweden. This produced a remarkable short-period (around 2.5 seconds) microseismic storm at Karlskrona, quite near the cyclonie center. But there was almost nothing at Uppsala which is only about $350 \mathrm{~km}$ apart.

The same results are clearly observed in Japan. When a cyclone runs over the Pacific Ocean from south to north, the microseismic storm shifts gradually from southwestern stations to northeastern, as if it runs after the cyclone. In other words, microseismic storms in Japan occur quite independently at many places located near each other.

Passages of energy sources across the Baltic Sea hardly increase microseismic amplitudes even at Uppsala, as far as those with periods of more than 4 or 5 seconds are concerned. However, a small amplitude 
increase is observed at Uppsala for microseisms of shorter periods. The reason may be that the area of the Baltic Sea is not large enough to prorluce long-period swell.

c) When there is a single cyclone far off Scandinavia over the ocean, only the period of microseisms increases remarkably with a great time lag. In all cases these time lags agree quite well with the estimated travel times of swell of twice the microseismic period from an area at a certain distance from the cyclonic center to the nearest Norwegian coast. This result confirms the writer's previous conclusion (Santo 1960) that microseisms are produced by stationary swell, due to interference between incident and reflected swell at steep coasts. As the swell from a distant source reaches the coast with long period but small amplitude due to the dispersion, our conclusions are quite reasonable.

When there are several cyclones over the ocean with swell arriving at the same coast at the same time, the microseismic period storn does not always show up, even if one of them is located far off the coast. In this case long-period swell from the distant source will be disturbed by swell from other sources.

There are a few cases when a distant source approaches the coast faster than the swell, which had been delivered from the cyclone in an earlier position. In these cases, the increase of microseismic periods, expected from the swell arrival, is not observed.

d) From the theoretical study by Longuet-Higgins (1950) and the experimental investigation by Cooper and Longuet-Higgins (1951), it is well known that the water pressure variation due to standing sea waves propagates downward to the bottom of the sea without attenuation. There is certainly a possibility that standing sea waves will also be generated by interference of two wave systems from two cyclonic centers. Geddes (1958) has actually found that microseismic amplitudes increase when coupled cyclones appear over the ocean.

There are many such situations in the present investigation, and the writer carefully searched for microseisms due to such cases. But, this was unsuccessful. The reason that we cannot find any effect of coupled cyclones over the ocean on microseisms may be due to the poor transmission of microseismic waves under the ocean (Båth 1953 and Monakhov 1959, 1960).

e) There are many cases when large cyclones pass quite near the coasts of Greenland, Iceland or the British Isles. These cyclones must cause large microseismic storms on these islands. The microseismic 
amplitudes in Sweden, however, do not show any increase in any such case. From these facts, we have to suggest that the transmission of microseismic waves is quite poor from these lands to Scandinavia. The reason is again the poor transmission across the ocean floor.

\section{APPENDIX.}

When a cyclone passes over the ocean off the coast, the microseismic amplitudes at a station on land become largest later than the time of nearest passage of the cyclone. Through the investigations of microseisms recorded at eleven stations in Japan, it was found (Santo 1960) that this time lag depends upon several quantities (Fig. 23): the distance from the coast to the path of the cyclone $(D)$, the intensity of cyclone $\left(p_{o}\right)$, the travelling velocity of the cyclone $(V)$ and even upon the side of the coast facing the path of cyclones.

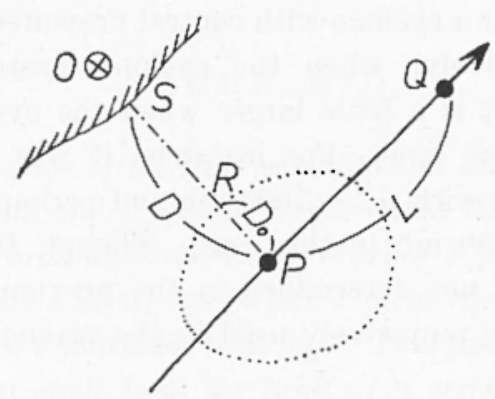

Fig. 23 - Schematic figure for explanation of the concept "eye of microseismic storm".

The conception of the "eye of microseismic storm "was introduced by the present writer in order to explain the time lag phenomenon.

In Fig. 23, Q means the position of a cyclone at the time of maximum microseismic amplitudes at the station $\mathrm{O}$, and $\mathrm{P}$ is the nearest position of the cyclone. The writer investigated the relation between $L(=\mathrm{PQ})$ and $D(=\mathrm{PS})$ from observations at many stations in Japan for 11 cyclones and 7 typhoons and the following empirical relation was found to be valid:

$$
D\left(p_{o}\right)=v\left(p_{o}\right) L / V+D_{o}\left(p_{o}\right)
$$

in which $v$ - group velocity of swell, $r=$ travelling velocity of cyclone, 
and $D_{0}=$ an additive term which depends upon the central pressure of the ryclone $\left(p_{o}\right)$.

The physical meaning of the term. $D_{o}\left(p_{o}\right)$ can easily be understood if we change equation [1] into the following:

$$
\left(D-D_{o}\right) / v=L / V
$$

This equation has the travel time dimension. Therefore, the numerator of the left-hand side of this equation corresponds to the path length of the swell. Then, the physical meaning of this empirical result is as follows:

The microseismic amplitudes at the station O become largest when the swell from the limit of the hypothetic region around the eyclonic: center reaches some coast near the station. This hypothetic regrion around the cyclonic center was named "eye of microseismic storm". The term $D_{o}\left(p_{o}\right)$, therefore, means the radius of this "eye" against the land. Arecording to previous results, $D_{0}$ was estinated as about $50 \mathrm{~km}$ and $300 \mathrm{~km}$ for a cyclone with central pressures of about $1000 \mathrm{mb}$ and $970 \mathrm{mb}$ respectively, when the eyclone passes on the left-hand side of the land. $D_{o}$ is a little larger when the cyclone passes on the righthand side of the land. For instance, it was found to be about $100 \mathrm{~km}$ for a cyclone with $p_{o}=1000 \mathrm{mb}$ and perhaps about $600 \mathrm{~km}$ for a cyclone of $p_{0}=950 \mathrm{mb}$ in this case. Though $D_{o}$ for cyclones with other intensities was not determined in the previous investigation, the following values were tentatively used in the present paper:

\begin{tabular}{|c|c|c|}
\hline Central pressure & $\begin{array}{c}\text { Cyclone } \\
\text { on left-hand side }\end{array}$ & $\begin{array}{c}\text { Cyclone } \\
\text { on right-hand side }\end{array}$ \\
\hline & & \\
\hline $1000 \mathrm{mb} \leqslant p_{o}$ & $50 \mathrm{~km}$ & $100 \mathrm{~km}$ \\
$990 \mathrm{mb} \leqslant p_{0} \leqslant 999 \mathrm{mb}$ & $100 \mathrm{~km}$ & $200 \mathrm{~km}$ \\
$980 \mathrm{mb} \leqslant p_{o} \leqslant 989 \mathrm{mb}$ & $200 \mathrm{~km}$ & $300 \mathrm{~km}$ \\
$970 \mathrm{mb} \leqslant p_{0} \leqslant 979 \mathrm{mb}$ & $300 \mathrm{~km}$ & $400 \mathrm{~km}$ \\
$960 \mathrm{mb} \leqslant p_{0} \leqslant 969 \mathrm{mb}$ & $400 \mathrm{~km}$ & $500 \mathrm{~km}$ \\
$950 \mathrm{mb} \leqslant p_{o} \leqslant 959 \mathrm{mb}$ & $500 \mathrm{~km}$ & $600 \mathrm{~km}$ \\
$p_{0} \leqslant 949 \mathrm{mb}$ & $600 \mathrm{~km}$ & $700 \mathrm{~km}$ \\
\hline
\end{tabular}




\section{AChNOWLEDGMENTS.}

The research reported in this paper has been carried out at the Seismological Institute, Uppsala, and was made possible through the support and sponsorship of the U.S. Department of Army, through its European Research Office (Contract No. DA-91-591-ELC-1637, Mod. 1). The writer would like to express his sincere thanks to the institutions.

The writer's great thanks are also due to Dr. Narkus Båth, who gave him a valuable opportunity to do his work at Uppsala and gave him much help and advice during investigation.

The measurements of microseisms at Uppsala and Firuna, used in this paper, were made by the stafi members of the Seismological Institute, Uppsala, in the course of the I.G.Y.

Seismological Institnte, Uppsala, Sweden

October, 1962

\section{$S^{\prime} U M M A R \mathrm{I}$}

Comparative studies of the time variations of microseismic amplitudes and periods at Kiruna and Uppsala, stweden, and the corresponding meteorological situations around Scandinavia during T.G.Y. were made.

A distant cyclone over the ocean has a great effect only on the periods of microseisms with a rematable time lag. This time lag is well explained by the travel time of suell from the limit of a certain region around the cyclonic center to the nearest Norwegian coust.

The effect of double or triple cyclones upon the microseisms is more obscure, as different effects mask each other.

The transmission of microseismic waves from the southern Norwegian coast to Uppsala is less efficient than from the northern coast to Kiruna. The vertical amplitude ratio of microseisms Kiruna: Uppsala from a source at the northern coast is in average about $1: 0 . j$.

Transmission of microseismic waves beneath the ocean is found to be quite poor.

\section{RIASEUNTO}

Sono stati eseguiti a Kiruna e Uppsala (Svezia) studi comparativi fra le variazioni nel tempo delle ampiezze e dei periodi dei microsismi, e la 
corrispondente situazione meteorologica intorno alla Scandinavia durante l'I.G.Y.

Un ciclone oceanico lontano ha grande effetto, con notevole ritardo, solo sui periodi dei microsismi. Questo ritardo è giustificato dalla più lenta propagazione del moto ondoso dal limite di una certa area intorno al centro ciclonico alla piu vicina costa Norvegese.

L'effetto di cicloni multipli sui microsismi è pivi complesso, interferendo $i$ diversi effetti gli uni sugli altri.

La propagazione delle onde microsismiche dalla costa meridionale della Norvegia a Cppsala, è meno evidente di quella che avviene dalla costa settentrionale a Kiruna. Il rapporto fra le ampiezze verticali delle onde microsismiche Kimun: Oppsala, è in media di circa $1: 0 . j$.

La propagazione delle onde microsismiche sul fondo dell'oceano è risultata pressochè nulla.

\section{REFERENCES}

BATr M., An Investigation of the Uppsala Microseisms. "Medd. Met. Inst. Uppsala", 14, 168, (1949).

- The Microseismic Importance of Cold Fronts in Scandinavia. "Arkiv för Geofysik", I 12, 267-358, (1951 a).

- The Distribution of Microseismic Energy with Special Reference to Scandinavia. "Arkiv for Goofysik", I 13, 359-393, (1951 b).

- Review over Investigations of Microseisms in Scandinavia. "Pont. Acad. Sci., Scripta Varia", 12, 239-276, (1952 a).

- The Microseismic Time Lag Problem. "Pont. Acad. Sci., Scripta Varia", 12, 279-289, (1952 b).

- Comparison of Microseisms in Greenland, Iceland and Scandinavia. "Tellus", V 2, 109-134, (1953).

- Direction of Approach of Microseisms "Geophys. Jour. Roy. Astr. Soc.", 6, 450-461, (1962).

Cooper R. I. B. and Longuet-Higgins M. S., An Experimental Study of the Pressure Tariations in Standing Sea Waves. "Proc. RoJ. Soc. A.", 206, 424, (1951).

Geddes A. F. M., A Survey of the Iricroseisms Recorded at Aberdeen in 1955, together with a Review of the Meteorological Conditions under Which They May Mave Arisen. "Bull. Seis. Soc. Amer.", 48, 65-76, (1958).

Longuet-Higgins M. S., A Theory of the Origin of Microseisms. "Phil. Trans. Roy. Soc. London A.", 243, 1-35, (1950).

Monakiov F. I., The Conditions of Generation and Propagation of Microseisms through the North Atlantic Ocean (in Russian). "Seism. and Glacio. Res. during I.G.Y.", 2, 39-57, (1959). 


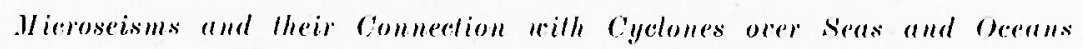
(in Russian1). " seismological Research $", 4$, 78-104, (1960).

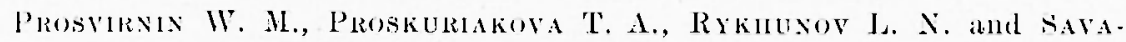
RENSKY L. F., The Influence of the Topography of Scandinavia on the Propagution of Microseisms (in Russianl). "Neism. ind (ilacio. Res. during 1.G.Y." 2, 58-63, (1959).

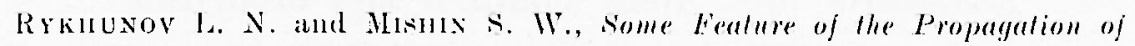

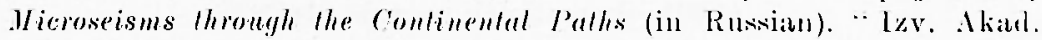
Nank sssR $\cdots, 6,810-817,(1962)$.

SAxto T. A., Investigations into llieroseisms Using the Obsereational Data of llany slations in Japan (Part I) -.. On the Origin of ll ioroseisms "Bull. biarthi. Res. Inst.", 37, 307-325, (1959 a).

- Ineestigation into llicroseisms Csing the Observational Datu of Many stations (Part II) - Further Considerations on the Origin of llicro. seisms _. "Bull. Larthq. Res. Inst." , 37, 483-494, (1959 b).

- The Observation of llicroseisms al " Ware Gauge Station -. On the Origin of llicroseisms (Part III) -. "Bull. Earthq. Res. Inst.", 38, 2+1-25t, (1960).

Isokt s., On the Speed, Traned T'ime and Direction of Ocean Waces due to Tropical Gyclones. "Jour. Meteo. Soc. Japan", 34, 354-371, (1956).

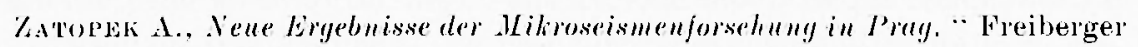
Forselhungshefte, G 101, Geophysil ". 36-48. (1961). 